\title{
PRELIMINARY SURFICIAL GEOLOGIC MAP OF THE WEBER SEGMENT, WASATCH FAULT ZONE, WEBER AND DAVIS COUNTIES, UTAH
}

By

\author{
Alan R. Nelson and Stephen F. Personius
}

\section{Overview}

This map, the fourth in a series of 1:50,000-scale maps of the Wasatch fault zone, depicts the surficial deposits and faults along the Weber segment and part of the adjacent Salt Lake City segment of the Wasatch fault zone in northern Utah (fig. 1). This is the first map that is sufficiently detailed to be useful for interpreting the paleoseismic history of this part of the Wasatch fault zone. The map is also a guide to the best sites for future detailed studies of paleoearthquake magnitude and recurrence on the segment. These types of geologic studies will form a quantitative basis for earthquake hazard assessment along the Wasatch Front.

One of the main objectives of our mapping of the Weber segment was to determine if the distribution of deposits and fault scarps between North Ogden and Bountiful indicated that this part of the fault has behaved as a single fault segment during the latest Pleistocene and Holocene, or whether it consisted of two or more segments. Most major normal and strikeslip fault zones are thought to be composed of several seismically independent segments (Zoback, 1983; Schwartz and Coppersmith, 1986; Doser, 1989; Thenhaus and Barnhard, 1989). Segments are often bounded by "non-conservative barriers" to fault-rupture propagation (Crone and others, 1987; Fonseca, 1988; dePolo and others, 1989; Thatcher and Bonilla, 1989). Nonconservative barriers are regions along a fault where the orientation of the slip vector changes between adjacent parts of a fault; these regions have been observed to mark the location of the initiation and termination of fault ruptures (King and Nabelek, 1985). The concept of fault segmentation is important to paleoseismic analysis of active fault zones because during a major earthquake, surface faulting is commonly restricted to one or two segments of the fault and the length of surface rupture is roughly proportional to the size of the earthquake.

Initial work on segmentation of the Wasatch fault zone, summarized in Swan and others (1980) and
Schwartz and Coppersmith (1984), identified si ${ }^{\times}$discrete fault segments, but recent work by a consortium of investigators has identified 10 or 11 segments (Machette and others, 1987, 1989, in press; Wheeler and Krystinik, 1988). In northern Utah, the Ogder and Collinston segments of Schwartz and Coppersmith (1984) have been separated into three new segments (fig. 1); northward from Salt Lake City, the $\mathrm{W}^{\top}$ eber, Brigham City, and Collinston segments have been delineated (Personius, 1986, 1988a; Machette and others, 1987, 1989, in press). Nelson and Personius (1987) suggested that the Pleasant View salient at the northern end of the Weber segment is a non-conservative barrier, and Bruhn and others (1987, p. 345) described th: Salt Lake salient at the southern end of the segment as a similar barrier.

Our mapping of deposits and young fault scarps shows that the Weber segment is perhaps the most geologically distinct segment of the Wasatch fault zone. Scarp heights in deposits of all ages decrease markedly near the segment boundaries and remnants of preBonneville-lake-cycle fans are selectively preserved in these areas (fig. 2). Gaps in Holocene faulting and significant differences in Holocene slip rates between the ends of the Weber segment and the adjacent Brigham City and Salt Lake City segments further support the mapped boundaries. Thus, scarp dis'ribution and faulted-surface offset data (fault throw) for the latest Pleistocene and Holocene show that the mapped northern and southern boundaries of the segmert are clearly zones where surface ruptures have tended to change direction and die out. Finally, the lower structural relief at the Pleasant View and Salt Lake bedrock salients, first recognized by Gilbert (1928), show: that these segment boundaries have probably peristed throughout the Quaternary (Wheeler and Krystinik, 1988).

The Weber segment is also one of the longest (61 $\mathrm{km}$ ) and most active segments of the Wasatch fault zone. Although all large Pleistocene and Holocene earthquakes probably did not rupture the entire V/eber segment, empirical fault rupture length-magnituda and 
fault displacement-magnitude relationships (Bonilla and others, 1984; Machette and others, 1989) suggest that the magnitude of earthquakes that did rupture the entire length of the Weber segment may have been as large as $M 7 \frac{1}{2}$. The most recent (probable) event on the segment may have occurred only 500 years ago; average event recurrence is about 1,200 years, but recurrence intervals may vary from 300 to 2,200 years. Although another large-magnitude earthquake may not rupture the Weber segment for many hundreds of years, the vertical component of slip on the fault during the most recent event may have been smaller (probably $<0.6 \mathrm{~m}$ ) than the slip typical of most events (1-3 m), suggesting that the recurrence of large earthquakes may be markedly nonuniform; there may be sufficient present stress on the segment to produce a large event in the near future. Detailed site-specific trenching investigations at several more sites on the segment are needed to better define Holocene recurrence and the potential hazard of a M $61 \frac{1}{2}-7 \frac{1}{2}$ event.

The pattern of fault scarps along the Weber segment is highly variable, but we can make some generalizations about the character of the scarps. In some areas it is difficult to distinguish secondary fault traces from landslide scarps, lateral-spread headscarps, fluvial scarps, and lacustrine shorelines, but the main trace of the fault is usually obvious. The complexity of scarp patterns is partly a reflection of the age of the deposits on which the scarps are formed: more scarps tend to be preserved in older deposits or where thin young deposits are draped over preexisting scarps. Multiple parallel traces of the fault are usually best developed where the trend of the main scarp changes abruptly, such as at the mouths of larger canyons and at some small reentrants (embayments) in the mountain front. Many of the reentrants probably mark the location of preexisting structures that locally control the main trace of the fault (Gilbert, 1928). Over larger areas, trends of small scarps become more diverse and the mountain front bends abruptly westward near the Pleasant View and Salt Lake salients, which bound the segment on its north and south ends.

Scarp heights and surface offsets across the scarps are also highly variable along the segment, but they unquestionably decrease by at least a factor of two for all ages of deposits near both ends of the segment (fig. 2). The catastrophic fall of the level of Lake Bonneville from the Bonneville shoreline, the rapid fall in lake level from the Provo shoreline, the poorly consolidated deposits exposed along the mountain front, and the rapid relative rates of uplift of the footwall of the fault have resulted in a highly active geologic environment along the fault zone. Complex patterns of faulting, erosion, and deposition near the foot of scarps, slumping and erosion of fault-scarp crests, landsliding, and lateral spreading have produced a landscape in which sites with simple scarps that represent total vertical slip across the fault zone are rare. However, many sites have scarps that yield surface offsets that can be determined to be maximum or minimum values; such sites help constrain vertical slip values for uppermost Pleistocene and Holocene deposits along much of the fault zone.

As noted by Gilbert (1928), scarps of differing heights in deposits of different ages clearly indicate many surface-rupture events on the Weber segment since the fall of lake level from the Bonneville shoreline. In a few areas, systematic differences in scarps heights on upper Holocene fans show that there have been at least three faulting events during the late Holocene. Recent studies of trenches and exposures across the fault at three sites along the segment confirm that there have been at least three and probably four events on at least the northern half of the segment in the last 4,000 years (Nelson and others, 1987; Machette and others, in press). Typical vertical displacements for these events $(1.5-2.5 \mathrm{~m})$ and surface offsets $(0.5-1.5 \mathrm{~m})$ calculated from scarps on the youngest fans (probably $<2 \mathrm{ka}$ ) indicate that most scarps are the product of two or more events. Total post-Bonneville offset along much of the Weber segment is about $25-28 \mathrm{~m}$. Thus, there have probably been at least 10 and perhaps 15 surface faulting events in the past 15,000 years.

Slip rates show the same changes along the segment as the surface-offset values from which they are derived (fig. 2). The uncertainties in the ages of Holocene deposits along the fault far exceed the uncertainties in determining offsets; uppermost Pleistocene deposits are relatively well dated at $13-16 \mathrm{ka}$. Thus, even if we were able to greatly improve the accuracy of our offset values, the errors of our Holocene slip rates would remain large. Although post-latest Pleistocene slip rates are fairly uniform in the center of the segment, they may decrease more rapidly to the south than to the north. There may be significant changes in middle to late Holocene rates between the northern and southern halves of the segment that we cannot resolve because of dating uncertainties and the scarcity of Holocene deposits that cross the fault in the south. Similarly, there are suggestions that late Holocene slip rates north of Kaysville are greater than early and middle Holocene slip rates, but our present data are insufficient to confirm this preliminary interpretation.

Most other maps of this part of the Wasatch fault zone are reconnaissance maps showing a generalized main trace of the fault (Marsell, 1964; Morisawa, 1972; Van Horn, 1975; Miller, 1980; Davis, 1983, 1985; Bryant, 1984). Cluff and others (1970), who made the first detailed map of the fault zone, mapped three 
classes of lineaments of definite, probable, and possible tectonic origin, but only checked a few of these features in the field. Our mapping supports the interpretation of a tectonic origin for most of the definite (Class I) faults of Cluff and others (1970). No previous maps show Quaternary deposits along the Weber segment in more detail than Miller's (1980) map at 1:100,000 scale, and fault-scarp heights were measured at only a few sites in earlier studies (for example, Swan and others, 1980; Petersen,1981). In the following sections, we summarize the methods used to date and map the deposits and measure the fault scarps, and then follow with discussions of the (1) age, size, and distribution of deposits and scarps, and (2) slip rates derived from measurements of surface offsets along the northern, central, and southern parts of the Weber segment. Our conclusions about the Weber segment are presented in the first part of the overview section.

We used published geologic and soils maps of various scales that cover most of the map area as a guide in mapping (Feth and others, 1966; Erickson and Wilson, 1968; Cluff and others, 1970; Pashley and Wiggins, 1972; Van Horn, 1975; Miller, 1980; Currey, 1980; Anderson and others, 1982; Van Horn, 1982; Bryant, 1984; Crittenden and Sorensen, 1985; Keaton, 1986, 1988; Van Horn and Crittenden, 1987; Personius, 1988a; Personius and Scott, 1990; and unpublished landslide mapping by Earl Olson, U.S. Forest Service, Ogden); our primary sources are shown in the "Sources of Geologic Data." The bedrock geology of the uplifted mountain block was compiled from maps by Van Horn (1981), Bryant (1984), Crittenden and Sorensen (1985), and Van Horn and Crittenden (1987). Nelson did the mapping north of Kaysville and near Bountiful; Personius did most of the mapping of the south boundary of the segment and the area between Centerville and Kaysville. Because we focused our project on the fault zone (the area of scarps in unconsolidated deposits at the base of the mountain front), mapping detail varies from place to place on the map. Features within $1 \mathrm{~km}$ of the fault zone were mapped in detail, whereas those near the edges of the map were largely compiled from earlier maps and 1:60,000-scale aerial photographs. Most of the mapping was done in the field on 1:10,000scale aerial photographs flown in 1952 and 1953 by the U.S. Soil Conservation Service; some use was also made of 1:12,000-scale low-sun-angle aerial photographs of the fault zone flown in $\mathbf{1 9 7 0}$ for the Utah Geological and Mineral Survey. Faults that are marked by scarps of tectonic origin are delineated by a thick, solid line. The geomorphic position (at base of the mountain front), height, trend, and continuity of scarps are our main criteria for judging whether scarps are of tectonic or nontectonic origin. Dashed lines show faults whose location is less certain, for example, in areas where high, steep scarps occur on Bonneville shoreline deposits. Scarps that are of uncertain origin but are probably faults are shown as dashed-and-queried lines. Two areas within the main map area are included as detailed 1:10,000-scale maps (figs. 3 and 4).

\section{ACKNOWLEDGMENTS}

Funding from the National Earthquake Hazards Reduction Program, and the cooperation of landowners who granted us access to their land, made this manping possible. We also thank many individuals for their extensive discussions with us and for providing unpublished information, especially Richard Van Horn (USGS, Denver, Colo.), Fred Pashley (Weber State College, Ogden, Utah), Jeff Keaton (Sergent, Hawkins, and Beckwith, Inc., Salt Lake City, Utah), Mike Lowe (Utah Geological and Mineral Survey, Salt Lake City, Utah), Dave Schwartz (USGS, Menlo Park, Calif.), Jim McCalpin (Utah State University, Logan, Utah), and Earl Olsen (U.S. Forest Service, Ogden, Utah). The Utah Geological and Mineral Survey, through the efforts of Bill Lund and his staff, provided extensive financial and logistical support for the trenching study at the East Ogden trench site. Mike Machette previded guidance and encouragement. Many weeks of map complilation and drafting by Rene Evans and Greg Pudlick are much appreciated. Thorough revie'ws by Bob Bucknam and Ralph Shroba (USGS, Dinver, Colo.) significantly improved the map and text.

\section{AGES OF QUATERNARY DEPOSIT,}

We used traditional morphostratigraphic methods (for example, Willman and Frye, 1970) as the baris for subdividing the Quaternary deposits along the $V^{\top}$ eber segment (informal allostratigraphic units of North American Stratigraphic Code; North American Commission on Stratigraphic Nomenclature, 1983). G rides to the relative age of deposits also included: (1) the degree of fluvial dissection of alluvial fans and stream terraces, (2) the extent to which braided channels are preserved on fan surfaces, or (3) the number of clasts per unit area on surfaces, which is a rough meas"re of the thickness of loess on surfaces. On some upper Holocene (unit af1) fans, the differing height of the youngest fault scarps helped distinguish the relative ages of parts of the fans. In these areas we subd:vided the fans using dot-dashed lines. However, th: age differences between these subdivisions are probably 
small and we were unable to confidently correlate these subdivisions from one drainage to another. For this reason, we mapped them all as deposits of late Holocene age.

The degree of soil development on landforms along the Weber segment was less useful in distinguishing deposits of different age than the above methods. Shroba (1982, 1984), Scott and others (1982), and Scott and Shroba (1985) have shown that differences in the degree of soil development along the Wasatch Front can be used to divide upper Pleistocene to upper Holocene deposits into as many as five relative-age groups. However, there are few exposures of uneroded soils along the Weber segment and most of the deposits along the Weber segment are either of latest Pleistocene (dating from transgressive or regressive phases of the Bonneville lake cycle) or late Holocene age. Using the degree of soil development to differentiate upper and middle Holocene fan deposits is also difficult because of the large range of clay content of soil parent materials in exposed debris-flow deposits on fans. Soil development on uppermost Pleistocene deposits is markedly stronger than on upper Holocene deposits (see unit descriptions), but near the fault zone these deposits can almost always be better distinguished on the basis of altitude and relations with lake shoreline features of known age.

Most Holocene units mapped as pre-upper Holocene (for example, units af2 and al2, and parts of unit afy) are of middle Holocene age. At one site east of Ogden, Nelson and others (1987; Nelson, 1988) used radiocarbon and thermoluminescence ages to show that the fans were deposited $<7 \mathrm{ka}$ (thousands of years ago); more recent thermoluminescence ages from this site and average fault-event recurrence intervals suggest these fans may have been deposited $<6 \mathrm{ka}$ (Forman and others, 1988). Soils on the alluvial fans at the east Ogden site are the most strongly developed Holocene soils that we found during our mapping. This relation suggests most Holocene deposits exposed along the Weber segment are $<7 \mathrm{ka}$.

We found that the easiest and most widely applicable way to map deposits of different ages along the Weber segment was to relate deposits to the Lake Bonneville shoreline features of known age. The following summary of the late Quaternary depositional history of the Bonneville basin and the Wasatch Front is largely taken from Scott and others (1983), Currey and Oviatt (1985), McCoy (1987), Currey and Burr (1988), and Scott (1988a). Lithologic characteristics of Lake Bonneville sediments in the Ogden area are described in more detail by Feth (1955) and Feth and others (1966).

Most of the surficial deposits along the northern Wasatch fault zone were deposited during the last pluvial lake cycle of Lake Bonneville (know'n as the Bonneville lake cycle) between 32 and $10 \mathrm{ka}$ and in the subsequent interpluvial, the Holocene $(<10 \mathrm{ka})$. During its initial transgressive phase, Lake Bonnoville began rising from a low level about $32 \mathrm{ka}$ and roce slowly, with several fluctuations and pauses, to the Bonneville shoreline (about 1,579 m (5,180 ft) above se level in map area) about $16 \mathrm{ka}$. After about 1,500 years at this level, the lake dropped to the level of tl a Provo shoreline (about $1,487 \mathrm{~m}(4,880 \mathrm{ft}$ ) in map area) as a consequence of catastrophic downcutting of th $:$ threshold at Red Rock Pass in southeastern Idaho. The resulting Bonneville Flood deposited debris northward onto the Snake River Plain (Malde, 1968; Jarrett and Malde, 1987). In many parts of the Wasatch Front, this rapid decline in lake level was accompanied by isostatic rebound and rapid erosion of Bonneville trar cgressive phase shoreline sand and gravel (units lbg anc' lbs) and deltaic deposits (unit lbd); much of this debris was redeposited as alluvial fan-delta complexes (units Ipd, alp, and afp) graded to the Provo shoreline near the mouths of major canyons. By 14.3 ka the lake level began to drop in response to further downcutting of the Red Rock threshold, isostatic rebound, and changing climatic conditions (warming or drying, or both). Lake Bonneville had fallen to a level below 1,372 $\mathrm{m}(4,500 \mathrm{ft})$ by $13 \mathrm{ka}$ and reached the level of modern Great Salt Lake $(1,283 \mathrm{~m}(4,210 \mathrm{feet}))$ about $11 \mathrm{ka}$; it then rose briefly to the Gilbert shoreline (1,295 $\mathrm{m}(4,2,50$ feet $))$ about $10.3 \mathrm{ka}$. During the Holocene the Great Salt Lake has remained within about $10 \mathrm{~m}$ of its present level (Currey and others, 1984).

As the level of Lake Bonneville dropped from the Provo shoreline, the largest streams downcut through the lake deposits along the mountain front while the smaller streams built alluvial fans at canyon mouths across the platform of shoreline sediments. These fans consist mainly of coalesced debris-flow deposits and stream deposits of latest Pleistocene(?) to late Holocene age (units afp, af3, afy, and af2). Our mapping suggests that few of these alluvial deposits of early Holocene age are still exposed at the surface, but are buried by alluvial deposits of late Holocene age (units af1 and al1, and parts of unit afy); large parts of most fans are covered by upper Holocene debris (units af 1 and cd1). Thus, in most areas, alluvial-fan deposits mapped as unit afy are more likely to be of late Holocene rather than early or middle Holocene age. Debris flows (unit cd1) continue to be a common hazard in some of the canyons, especially in the southern part of the map area; destruction occurred at the mouths of canyons during many flows between 1878 and 1983, especially in the 1920's and 1930's (Wieczorek and others, 1983, 1989). However, we did not attempt to map debris-flow depos- 
its of the last few hundred years at all canyon mouths - in most areas debris-flow deposits are included within unit af1.

Mapped deposits that significantly predate the transgressive phase of the Bonneville lake cycle are limited to eroded remnants of alluvial fans (unit afo). These remnants occur above the Bonneville shoreline, are much more dissected than younger remnants, and have eroded soils with thick, clay-rich, argillic B horizons. We have no other age information about these preBonneville deposits; if they are correlative with similar remnants described by Personius (1988a, b) on the Brigham City segment, by Personius and Scott (1990) on the Salt Lake City segment, and by Machette (1984, 1989 ) in Utah Valley, they are probably several hundred thousand years old. The only remnants of mappable size are preserved north of North Ogden near the north boundary of the Weber segment and south of Bountiful near the south boundary of the segment; there are also a few small remnants near Hobbs and Holmes Reservoirs south of the Weber River. We speculate that these old fan remnants are only preserved near the boundaries of the segment because rates of late Quaternary uplift have been highest along the central part of the segment; accelerated erosion due to rapid uplift has probably removed older remnants everywhere except at the segment boundaries, where rates of uplift and erosion are lower.

\section{METHODS OF SCARP MEASUREMENT}

Our objective in calculating the amount of vertical offset or displacement of geomorphic surfaces from measured topographic profiles across fault scarps was to calculate slip rates for deposits of different ages along this part of the Wasatch fault zone (fig. 2). Slip-rate calculations from a sufficient number of sites can be used to determine whether rates have been increasing or decreasing since the late Pleistocene, and whether rates during different time periods are similar along the length of the Weber segment. By assuming a characteristic earthquake model that produces surface scarps of relatively uniform height, slip rates can also be used to estimate earthquake recurrence on the segment (for example, Wallace, 1970; Schwartz and Coppersmith, 1986).

Terminology used to describe fault-scarp parameters follows Bucknam and Anderson (1979) and Machette (1988). Two values used to describe the amount of vertical separation of surfaces along a fault zone are fault-scarp height and surface offset. Scarp height is the vertical distance from the base to the crest of a scarp, whereas surface offset is the vertical component of fault slip (other equivalent terms are throw and net vertical tectonic displacement) measured by projecting a geomorphic surface across a fault or fault zone. Scarp heights were calculated from scarp-profile data only for comparison with other studies (for example, Machette, 1982) that use scarp-height data rather than surfaceoffset data. Surface offset is typically less than scarp height because most fault scarps occur on sloping surfaces. Surface-offset values only approximate the down-dip slip on the fault for steeply dipping faults (exposures along the Weber segment suggest most surface faults dip about $65^{\circ}-85^{\circ}$ ). For this reason, our surface-offset data probably slightly underestima ${ }^{+}$dipslip separation on the fault. Where the fault zone consists of a broad zone of deformation that in ludes fault scarps, grabens, and surfaces that are back-tilted toward the main scarp, the surface offset may $b$ less than half of the height of the highest scarp in the zone.

We determined surface offset from 77 profiles measured across scarps in the field and from an additional 298 profiles measured from scarps visible on 1:10,000scale aerial photographs using the U.S. Geo'ngical Survey's computer-assisted PG-2 photogrammetric plotter. Field profile data were collected with an Abney level using either the method of Bucknam and Anderson (1979) or a slope pantometer in brushy terrain (Pitty, 1968). In some areas, we used 1952 aerial photography to measure profiles across scarps that were destroyed as many as 30 years ago by urtanization. All sites in the areas of figures 3 and 4 for which we calculated scarp heights and surface offsets (shown in parentheses) are shown on those 1:10,000-scale maps, but space limitations on the $1: 50,000$-scale man prevented showing the location of more than a few of the total 375 profiles. All locations and additional scarp profile parameters, such as upper and lower surface (far field) slope angles, average scarp-slope angles (maximum scarp-slope angles cannot be measured with the PG-2 plotter), and estimates of errors in offset and height values are available from the senior author.

We measured scarp profiles only to obtain surface offsets and scarp heights. Methods of scarp profile analysis used to determine relative ages of scarps (for example, Nash, 1984; Mayer, 1984; Hanks and others, 1984; Pierce and Colman, 1986) were not useful along the Weber segment because: (1) most of the scarps are composite scarps (the product of several faulting events), (2) scarp faces of profiles measured with the computer-assisted plotter are not detailed enough to justify use of these methods of scarp analysis (average scarp-slope angles measured with the plotter unterestimate angles measured in the field by 10-20 percent), and (3) materials exposed in scarp faces vary widely in lithology and degree of matrix cementation. Surface- 
offset values calculated from field and plotter profiles of the same scarps (one profilc by each method for 97 scarps) are similar; most paired offset values differ by $<10$ percent and none differ by $>25$ percent. This variation in offsets calculated from the two different types of profiles is about the same magnitude as the amount of error in calculating offsets from fieldmeasured profiles on the Weber segment, especially for scarps $>5 \mathrm{~m}$ high where, as is usually the case, surfaces above and below the scarps slope at significantly different angles.

Only about 15 percent of our scarp profiles give surface-offset values that are within 10 percent of the total vertical offset across the fault zone during the time elapsed since deposition of the map units at the profile sites. Most profiles (about 75 percent) yield minimum offsets because: (1) colluvial or fluvial sediments have buried the base of many scarps, (2) the upper surfaces of some scarps have been rounded by erosion on their lower edges and colluvial deposition on their upper edges, or (3) offsets have been measured across only one or two of a series of multiple scarps in the fault zone. About 10 percent of the profiles yield maximum offsets because: (1) young alluvial-fan sediments are draped over preexisting scarps, (2) reconstruction of prefaulting topography is difficult because the scarps trend through shorelines or other irregular topography, and (3) erosion or landsliding (especially lateral spreading) has increased the height of the scarp. Despite the fact that only about 15 percent of the profiles provided finite offsets for the major time periods, our minimum and maximum offsets place reasonable constraints on slip rates in several areas (fig. 2). In a few areas, slip rates are well constrained because minimum and maximum offsets were about the same.

The uncertainties in our slip rate calculations (fig. 2) are large because of the uncertainty in the numerical ages of some deposits at specific sites along the fault. Uncertainties due to errors in calculating offsets across scarps are probably $\pm 10-30$ percent; this value is smaller than the typical variation in height of scarps along a fault formed during an earthquake. For example, diagrams in Crone and others (1987, fig. 4) and Wheeler (1989, fig. 1) show great variation in scarp height for scarps produced by historic earthquakes on normal faults. In contrast, errors in estimating the numerical age of Holocene deposits at many sites on the Weber segment are as much as $\pm 50-100$ percent. However, deposits that can be confidently correlated with the Provo or Bonneville shorelines have an age uncertainty of $<15$ percent. The history of the last lake cycle of Lake Bonneville outlined above and the few radiocarbon ages available from the Weber segment (see Schwartz and Coppersmith, 1984; Nelson, 1988; Ma- chettc and others, 1987, in press) suggest the following approximate ages for most of our map units: upper Holocene, 0-4 ka (for example, unit af1; many of these deposits are probably $<2 \mathrm{ka}$ ); middle and lower Holocene, 4-11 ka (for example, unit af2; most of these units are probably $<7 \mathrm{ka}$ ); uppermost Pleistocene, 13-10 ka (for example, units afp and lbpm). We use these age ranges and errors in offset values to calculate probable errors for slip rates at specific sites. Where we discuss slip rates along a part of the Weber segment we quote a range of rates that includes probable errors in the rates along this part of the segment (fig. 2). These slip rate errors are large and they have not been rigorously determined because of the large age uncertainties, especially for middle and lower Holocene deposits.

Users of this map for hazards assessment, regional tectonic analysis, or related studies should remember that we show only faults and probable faults that are marked by scarps visible on 1952 and later acrial photography. In developed areas, such as on the east edges of Ogden and Bountiful, some scarps were destroyed before 1952, and in many areas scarps visible on acrial photography were destroyed before our field studies in 1985. Furthermore, although most scarps are the product of surface offset during a series of earthquakes, some new scarps form during most large $(>M$ 7) earthquakes. In a number of areas along the Weber segment, alluvial deposits of late Holocene age cover older scarps that may be only a few thousand years old. If the fault ruptures along these relatively young but buried scarps during a future earthquake, new scarps will be produced. Thus, this map gives a conservative portrayal of likely sites for future surface ruptures along the Weber segment.

\section{LATEST PLEISTOCENE AND HOLOCENE FAULTS OF THE WEBER SEGMENT}

Our mapping and relative dating of Quaternary deposits and associated fault scarps along the Weber segment allow us to make a moderately detailed irterpretation of the latest Pleistocene and Holocene history of faulting along this part of the Wasatch fault zone. Below we briefly summarize the age, size, and distribution of fault scarps on the Weber segment, and the slip rates calculated from this data. We start at the north boundary of the segment north of North Ogden, continue with descriptions of features produced by faul ing on the northern, central, and southern parts of the Weber segment, and finish with a description of the south boundary of the segment southwest of Bountiful. Our subdivision of the segment into northern, central, 
and southern parts is for convenience in discussing the characteristics and history of the fault zone-these subdivisions are not "subsegments" as used by Machette (1989).

\section{NORTHERN PART OF THE WEBER SEGMENT}

\section{North boundary of the Weber segment}

Scarps at the northernmost end of the Weber segment (north of the North Ogden rockslide) trend northwestward along the mountain front northeast of North Ogden and offset upper Holocene alluvial-fan deposits (unit af1) at all canyon mouths before terminating in Barrett Canyon about $3 \mathrm{~km}$ north of North Ogden (fig. 3). Because the trend of the canyon is the same as the trend of the main trace of the fault we infer that the fault (shown with dashed-and-queried line) extends some distance up the east edge of the canyon. Although we have not mapped any scarps on the Weber segment west of Barrett Canyon, the fans in this area are very young (probably $<2 \mathrm{ka}$ ), so some late Holocene scarps are probably buried by younger alluvial deposits or have alluvium draped over them. Most scarps in the late Holocene fans near the segment boundary are $<3 \mathrm{~m}$ high, but the discontinuity of scarps across unit af 1 deposits of slightly different age at the mouths of the major canyons (surfaces of slightly different ages on fig. 3 are distinguished by dotted-dashed lines) indicates that multiple fault events have occurred here in the last few thousand years. Scarps in the youngest deposits are commonly $<1 \mathrm{~m}$ high, suggesting that either the latest event had an average offset of $<1 \mathrm{~m}$ or that offsets decrease towards the segment boundary. As is true throughout most of the segment, zones of very complex faulting are located most commonly on the fans at canyon mouths rather than along intercanyon parts of the fault zone. Multiple and composite scarps that are too complex to show at the scale of figure 3 are well preserved in thick oakbrush near the mouths of some canyons north of the North Ogden rockslide.

Most offsets (shown on fig. 3) near the north boundary of the segment are calculated from scarps on upper Holocene deposits. Scarps in areas of older Holocene fan deposits reflect several events, but slip rates throughout the Holocene at this end of the Weber segment are about $0.5-1.2 \mathrm{~mm} / \mathrm{yr}$. Offsets from the older surfaces are usually minimum values because at most sites younger alluvium has been deposited against the downthrown side of scarps. Limited data (not shown on fig. 2) at two sites in the northern boundary area suggest post-Bonneville rates may be as low as 0.7 $\mathrm{mm} / \mathrm{yr}$.
The southern terminus of the Brigham City segnent is separated from the Weber segment by a 2-km-wide gap in late Quaternary fault scarps (Personius, 1986; Nelson and Personius, 1987; Personius, 1988b). The Weber-Brigham City segment boundary is located adjacent to a foundered bedrock block known as the Pleasant View spur (Gilbert, 1928) or salient, which is discussed in more detail by Personius (1988a, b). This relatively flat-topped bedrock outlier is capped with remnants of a middle Pleistocene alluvial-fan complex (unit afo, fig. 3) and Bonneville-lake-cycle deposits. Where these older fan remnants are not covered by Bonneville-lake-cycle deposits, the surface is broken by Quaternary normal faults of various orientations. Several other faults on the west flank of the Pleasant View salient postdate the Bonneville lake cycle and may have moved in response to earthquakes originating on the Weber and (or) Brigham City segments (Personius, 1988b). The Quaternary faults on the Pleasant View salient appear to be part of a network of subs:diary faults (the "process zone" of King and Nabelek, 1985) that may diffuse the energy of earthquake ruptures propagating into the salient.

The Weber-Brigham City segment boundary is also marked by an apparent change in the rate of late Holocene faulting. The main trace of the Brigham City segment between the Pleasant View salient and the range front is obscured in most places by thick oakbrush, but where scarps are visible, they are present primarily on deposits of middle to early Holocen a age or older. Scarp data on the Brigham City segment suggest that high rates of surface faulting occurred in latest Pleistocene to middle Holocene time, but that tectonic activity may have slowed or ceased along the Brigham City segment in late Holocene time (Frrsonius, 1988b). In contrast, fault scarps with $2-5 \mathrm{~m}$ of surface offset are common on deposits of late Holocene age on the northern part of the Weber segment. Thus, the major change in late Quaternary faulting antivity between the Weber and Brigham City segments is the abrupt change in the number and size of late Holocene fault scarps north across the Pleasant View saliert.

\section{North Ogden rockslide-North Ogden Canyon srea}

About $3 \mathrm{~km}$ southeast of Barrett Canyon is a large, hummocky, lobate landslide first mapped by Ecrdley (1944, pl. 2) and named the North Ogden rockslite by Pashley and Wiggins (1972). The rockslide extends from an altitude of 1,487 to $1,743 \mathrm{~m}(4,878-5,720 \mathrm{ft})$, bracketing the altitude of the Bonneville shoreline (here about 1,585 m $(5,200 \mathrm{ft}))$. The lack of a p"ominent shoreline cut into the rockslide deposits led Cluff and others (1970, fig. 18), Pashley and Wiggins (1972), 
and Van Horn and others (1972, fig. 12) to infer that the slide postdated the high stand of Lake Bonneville. However, the oldest (southernmost) lobe of the slide has somewhat more rounded, gentler topography than the younger lobes to the north. Possibly, the lake transgressed across this lobe and part way up the adjacent lobe to the north; if so, the coarse quartzite rubble of the slide lobes was resistant enough to wave erosion and entrainment by shore currents that a distinguishable shoreline did not form. The openwork structure of the coarse quartzite debris of the slide above the Bonneville level has prevented fine material from accumulating on the surface; therefore soils, which could be used to estimate an age for the slide, are absent. Weathering rinds and iron-oxide coatings on the surface of clasts on the upper part of the slide suggest many thousands of years of exposure.

We think the slide either just postdates the high stand of the lake about $15 \mathrm{ka}$, or, perhaps, is even older despite the lack of a distinguishable shoreline at the Bonneville level. A very large scarp (20-40 m high) trends northward across the middle of the slide deposits (fig. 3). Pashley and Wiggins (1972, fig. 1) interpreted this scarp as the front of a slide lobe, but the scarp is very steep and it is on trend with the main trace of the Wasatch fault. It seems unlikely that the coarse, openwork quartzite debris that is exposed in the scarp face has the mechanical properties needed to form the steep front of a rockslide lobe, unless huge, buried blocks of quartzite are supporting the front of the lobe. Thus, much of the height of the scarp is probably due to displacement on the fault. In addition, a series of smaller scarps trend north across the surface of the slide lobe above the high scarp (fig. 3) indicating that total offset across the slide lobes may exceed $50 \mathrm{~m}$. Dividing the probable offset across the scarp (30-50 m) by the highest post-Bonneville-age slip rate measured anywhere on the Weber segment gives a rough age of 14-24 ka. Thus, either (1) almost all of the height of the largest scarp is depositional, that is, not tectonic, (2) the slide closely postdates the high stand of the lake and slip rates on the fault here are very high (2-3 mm/yr), or (3) at least the lower two lobes of the slide are older than 15 $\mathrm{ka}$ and the Bonneville shoreline is poorly developed across the slide. We favor the third alternative.

South of the North Ogden rockslide the fault is expressed primarily as a single trace in Bonnevillelake-cycle deposits near the base of the mountain front. The high, steep slope of the front here promotes rapid erosion and burial of small scarps that may have formed near the main fault. At Rice Creek Spring, on the south edge of the North Ogden rockslide, fan remnants of at least four relative ages offer one of the best sites on the Weber segment for investigating post-Bonneville fault slip rates. Pashley and Wiggins (1972, fig. 1) m ’ped a landslide lobe that extended south from the North Ogden rockslide into Rice Creek Spring, but ve map this area as Holocene fan deposits that probably cover landslide deposits. At the mouth of North Ogden Canyon, reliable offset information comes from profiles across several fan remnants (unit afp) of different altitude graded to the Provo shoreline, across at least one middle to lower Holocene fan (unit af2), and across two upper Holocene alluvial surfaces. Near the mouth of Coldwater Canyon, parallel scarps of $3.2 \mathrm{~m}$ and $2.8 \mathrm{~m}$ offset on the south edge of a large fan help distinguish two upper Holocene surfaces of different ages (fig. 3).

Scarps at the canyon-mouth sites discussed above indicate a rapid increase in slip on the fault towards the south. These scarp data suggest late Holocene slip rates of about 1.0-2.3 mm/yr and rates of about 1.1-1.8 $\mathrm{mm} / \mathrm{yr}$ for the post-middle Holocene and postBonneville periods between Coldwater Canyon and the North Ogden rockslide. The amount of offset of late Holocene scarps is almost twice the offset of scarps on the segment north of the rockslide; either there were larger individual surface offsets on the segment to the south or there have been more slip events to the south. In either case, the decreasing scarp offsets northward suggest that surface ruptures during individual fault events tend to die out towards the north end of the Weber segment.

\section{Garner Canyon area}

A fortuitous artificial exposure at the mouth of Garner Canyon, $2 \mathrm{~km}$ south of Coldwater Canyon, provides more direct evidence of the size of slip events on this part of the Weber segment. Four colluvial wedges, each produced following a displacement on the main trace of the fault, are exposed in the face of the scarp on upper Holocene stream and debris-f'ow deposits at this site (Machette and others, 1987, in press). The vertical component of displacement estimated from the wedge stratigraphy of each of the four events is about $1 \mathrm{~m}$ of vertical displacement per event, but the two earliest events were probably a few tens cf centimeters larger than the two most recent events (Nelson and others, 1987). Radiocarbon dating of the A-horizon sediment on the two youngest buried wedges suggests the two most recent events occurred about $0 . \varepsilon-1.2 \mathrm{ka}$ and 1.5-2.0 ka (Machette and others, 1987, in press).

Late Holocene slip rates calculated at Garnor Canyon using stratigraphic and scarp-profile data are about $1.2 \pm 0.3 \mathrm{~mm} / \mathrm{yr}$. A scarp with $21 \mathrm{~m}$ of offset in lacustrine gravel below the Provo shoreline (unit lpg) on 11 a north edge of the Garner Canyon fan is probably representative of post-Provo-level offset and yields a similar slip rate of about $1.4 \pm 0.2 \mathrm{~mm} / \mathrm{yr}$. 
From Coldwater Canyon to Jumpoff Canyon, on the northeast edge of the city of Ogden, the fault is marked by a single large scarp (10-22 $\mathrm{m}$ offset). An extensive area of fine-grc ined lacustrine sediment (unit lbpm) is deformed by lateral spreading in this area (Miller, 1980). North of Jumpoff Canyon this fine sediment mantles older landslide deposits (unit lbpm/cls) derived from the mountain front above the fault, indicating that some of the older landslides predate the transgressive phase of the Bonneville lake cycle (Nelson, 1988). Near the base of the mountain front Holocene landslide deposits bury grabens along the fault.

\section{Jumpoff Canyon area}

At the mouth of Jumpoff Canyon several scarps as much as $8.5 \mathrm{~m}$ high occur on the late Holocene fan surface. As many as six parallel scarps are found west of the main scarp (Gilbert, 1928, plate 6B). The pattern of scarps here may typify the pre-late Holocene pattern of faulting at the mouths of many other canyons along the segment; we infer that there are more scarps at Jumpoff Canyon because the upper Holocene fan deposits on the footwall are thinner than at most other canyons and these deposits may be draped over preexisting scarps. Exposures on the southern part of the Jumpoff Canyon fan complex show 0.8-2 m of upper Holocene alluvium overlying faulted blocks of unit lbpm; these are not rockslide deposits as suggested by Pashley and Wiggins (1972, fig. 7). Thus, surface offsets from this site are maximum values for the late Holocene because upper Holocene fan sediments have been draped over preexisting scarps in older deposits. Thicker upper Holocene fan deposits at many other sites bury all but the most recent scarps and, therefore, offsets at these locations may be more representative of late Holocene offsets.

A further complication at Jumpoff Canyon is the presence of headscarps produced by landsliding. In the southwestern part of the fan complex we interpret the 25-m-high scarp as a headscarp of a lateral spread like those to the north. Small slumps have also occurred along the main fault scarp bordering the fan complex on the east. Thus, the Jumpoff Canyon scarps illustrate the difficulty of distinguishing landslide headscarps from fault scarps (Gilbert, 1928; Nelson, 1988) and suggest that displacements on the fault (and accompanying ground motions) must have triggered some lateral spreads and landslides (Gilbert, 1928), especially shortly after the fall of the lake level from the Bonneville shoreline.

\section{Area north of the Ogden River}

From Jumpoff Canyon south to the Ogden River, extensive late Holocene fans bury the eastern edge of a large delta (unit Ipd) built by the Ogden River wl on the level of Lake Bonneville stood at the Provo shcreline. The distal parts of these fans (unit afy) may be of middle Holocene age. Gilbert (1928, left half $\mathrm{c}^{f}$ plate $12 \mathrm{~B}$, plate $18 \mathrm{~B}$, and fig. 26 ) shows views of the southernmost of these fans before the area was excavated during construction of a flood-control basin on the fan. Several grabens marked by sharp-crested scarrs near the heads of the fans adjacent to the main scarp and several scarps developed in very fresh-looking debris flows suggest faulting during the very latest $\mathrm{Ho}^{\prime}$ 'rene. Scarps here suggest a latest Holocene slip rate of $>2$ $\mathrm{mm} / \mathrm{yr}$.

Just north of the bluffs along the north side of the Ogden River, four parallel scarps on two Holocene fans (unit af2) at the East Ogden trench site (shown by Gilbert, 1928, plates 15A and 18A) were studied to obtain a more detailed history of faulting of the northern Weber segment (summarized by Nelson and others, 1987; Nelson, 1988; Machette and others, in press; A.R. Nelson, S.F. Forman, and J.P. McCalpin, unpub. data). At the site, fan remnants dating from the middle Holocene (unit af2) are displaced by faults, but have not been eroded or buried as have equivalent-ag?d fans at the mouths of most other canyons along the fault. Stratigraphic studies in five trenches show that there have been at least three, and probably four, s"rfacefaulting events on the two main faults marked by the west-facing scarps since the middle Holocene alluvial fans (unit af2) were deposited. Vertical displacements across the faults for each event range from 1.0 to $2.8 \mathrm{~m}$ for the three earlier events; the last of the throe was about half the size of the first two. The youngest (probable) event was small, about $0.6-0.8 \mathrm{~m}$.

The soils on these fans have a weakly develop?d, 20to $80-\mathrm{cm}^{-}$-thick argillic horizon with $7.5 Y R$ colo* hues, but the most recent thermoluminescence analyses suggest these deposits were faulted only 4,000 years ago. Based on surface characteristics, soil development, and position relative to late Holocene fan surfaces, these fan remnants are some of the oldest Holocene alluvial deposits along the Weber segment. Our dating at the East Ogden site indicates these deposits are probably $<6 \mathrm{ka}$.

Extensive ${ }^{14} \mathrm{C}$ and thermoluminescence dating of the stratigraphic units in the trenches (Forman and others, 1988) suggests that event recurrence since the fans were deposited has ranged from 300 to 2,200 years vith an average of about 1,400 years. The post-mid-Hc locene slip rate for the fault zone at the site is $2.8 \pm 0.4 \mathrm{~mm} / \mathrm{yr}$.

The extensive series of landslides in the bluffs on either side of the Ogden River are discussed by Pashley 
and Wiggins (1972, p. K9-K10). Some of these landslides are still active.

\section{CENTRAL PART OF THE WEBER SEGMENT}

\section{Area south of the Ogden River}

G.K. Gilbert (1928, plates 8B, 17B, and fig. 32) studied the area immediately south of the Ogden River near the City of Ogden Reservoir, where the fault is marked by two or three parallel scarps of 2-14 m offset on Holocene fan deposits overlying sediments of the Provo delta. He used observations about these scarps to support his theory about the coseismic origin of piedmont scarps in unconsolidated deposits, and to suggest that differences in rounding of the scarp crests show they are of different ages (Gilbert, 1928, p. 38; Nelson, 1988). Springs are found on trend with these scarps on the south edge of the floodplain of the Ogden River (E.F. Pashley, Jr., oral commun., 1985). However, shallow exposures show that upper and middle Holocene fan sediment was spread over preexisting scarps in Provo delta and older Holocene fan sediment; thus, the heights and degree of rounding of the scarps may not be representative of the age of the sediments on the surface of the fans. Unfortunately, most of these scarps have now been partially destroyed, although the two prominent scarps that cross an older landslide covered with fan deposits in the bluffs south of the river today look much as they did to Gilbert (1928, plate 8B).

The area near the City of Ogden Reservoir is also one of the sites where Gilbert studied slickensides and gouge at the base of the Cambrian Tintic Quartzite. He observed fault drag of beds of the Tintic along the fault plane of the main trace of the fault (Gilbert, 1928, plate 2B). He also mapped a northwest-trending "cross fault" that dipped $70^{\circ}$ to the southwest and joined the main trace of the Wasatch fault ( $40^{\circ}$ west dip) at this locality (Gilbert, 1928, fig. 7, p. 21). Gilbert used this cross fault as an example of how preexisting structures can control the trace of the fault.

The origin of a $1.5-\mathrm{km}$-long, west-facing scarp about $300 \mathrm{~m}$ west of the parallel scarps at the base of the mountain front is uncertain. The scarp is as much as 10 $m$ high and trends north-south through a residential area of the City of Ogden built on Provo-age delta deposits (unit lpd). Because of its size, distance from the mountain front, and location in deposits susceptible to lateral spreading (unit lbpm and unit $\mathrm{lbpm} / \mathrm{lpd}$; see Feth and others, 1966; Pashley and Wiggins, 1972, p. K11-K15) we have interpreted this scarp as the headscarp of a large lateral spread. There are similar head- scarps in similar materials north and south of Ogden, but residential development in this part of the city predates available detailed aerial photography. However, a tectonic origin for the scarp is certainly poss (for example, see Cluff and others, 1970, p. 20).

\section{Taylor Canyon area}

The mouth of Taylor Canyon was another area that interested Gilbert. He suggested that a thrust fault that trends toward the head of the fan controlled the trac: of the main fault at this site (Gilbert, 1928, p. 21, fig. 14) and attributed the single, very large scarp (11 $\mathrm{m}$ high, 9 m of offset) on upper Holocene alluvium at the head of the Taylor Canyon fan to post-Bonneville faul'ing (1928, plate 9B). The scarp at the fan head is the only scarp identified on the bouldery debris of the fan surface (Pashley and Wiggins, 1972, fig. 8). But if the scarp represents total or net offset across the fault zone at this site, $9 \mathrm{~m}$ yields an unreasonably high, late Holocene slip rate of about $6.0 \pm 1.5 \mathrm{~mm} / \mathrm{yr}$. No bedrock is exposed in the face of the heavily wooded scarp, but its steepness, height, and location at the mouth of a narrow, $V$-shaped canyon indicate it is cored with $k$ - $d$ rock, and that uppermost Holocene alluvium is draned over an older, multiple-event scarp.

\section{Area from Weber State University south to the: Weber River}

South of Taylor Canyon, the fault is expressed in most areas as a single large (10-34 m) scarp at or atove the Provo shoreline, but on the late and middle Holocene fans at the mouths of Waterfall and Strongs Canyons it breaks into two or three parallel strands. At Waterfall Canyon the easternmost of these strands climbs the mountain front and probably trends for about $2 \mathrm{~km}$ through gravelly deposits of the transgressive phase of Lake Bonneville (unit lbg). As in other similar areas to the south (for example, just north of the mouth of Weber Canyon), there are some small landslide scars and indistinct shorelines on this grarrelly shoreface slope below the Bonneville shoreline. We found it difficult to determine the origin of scarps with confidence on such steep, partly forested slopes, where fault scarps can be easily confused with shorelino or landslide scarps.

Farther south, from Buess Reservoir to some of the lowest terraces on the south side of the Weber River, the small (1-4 m high) scarps of antithetic faults, $30-120 \mathrm{~m}$ from the main scarp, mark grabens along the fault. Buess Reservoir and Uintah Reservoir both occupy grabens; Gilbert (1928, plate 17A) misinterproted the latter depression (located $1.6 \mathrm{~km}$ north of the 
Weber River) as a landslide feature. Grabens like these probably formed almost everywhere along the fault in this area, but many are now filled with younger alluvium and colluvium (units af1, afy, and ca) and are no longer visible.

South of Taylor Canyon and north of the Weber River, lateral-spread headscarps can be traced to within a few tens of meters of the main scarp of the fault; in these areas fault and lateral-spread scarps are easily confused. Many small faults observed during excavations on the campus of Weber State University (E.F. Pashley, Jr., oral commun., 1985) may be related to lateral spreads, or, perhaps, to grabens near the fault zone. We think the large, north-south-trending scarp just southwest of Buess Reservoir is a lateral-spread headscarp rather than a fault scarp as suggested by Pashley and Wiggins (1972, p. K5). Liquefaction features that may have been caused by carthquakes have also been observed in the campus area (Pashley and Wiggins, 1972, p. K15). Just north of the Weber River the extensive surface of the Provo-level delta is backtilted into the fault zone (Gilbert, 1928, plate 15B), although there is not enough tilting to be shown by the 20-foot contour interval on the Ogden 1:24,000-scale topographic map.

Slip rates based on offsets across the scarps in the area south of Taylor Canyon are high-about 1.1-2.8 $\mathrm{mm} / \mathrm{yr}$ for the late Holocene and 1.2-1.9 mm/yr since the latest Pleistocene (fig. 2). Few sites have scarps on deposits of middle or early Holocene age in this area, but we obtained offsets from scarps on upper Holocene alluvium at the mouths of most of the major canyons. Several sites on the main scarp between Buess Canyon and Dry Canyon also provide post-Bonneville offsets on the fault. One of the largest post-Bonneville offsets (34 $\mathrm{m})$ on the Weber segment comes from a measurement across two small remnants of what must have been an extensive delta graded to the Bonneville shoreline just north of Spring Creek. Smaller offsets $(<28 \mathrm{~m})$ elsewhere along the fault suggest that the hanging wall of the fault at this site is within a large graben and (or) has been lowered by lateral spreading, making the 34-m offset a maximum value. Wood (1984) obtained a very high uplift rate of $4 \mathrm{~mm} / \mathrm{yr}$ for the last 25 years using geodetic data at the mouth of Weber Canyon, but short-term historic rates like these need not agree with long-term Holocene rates.

Almost the entire area west of the fault zone between the huge deltas built by the Ogden and Weber Rivers (unit Ipd) is a complex of hummocky, lateral-spread and landslide deposits (Pashley and Wiggins, 1972, p. K12-K15). Most of the deformed sediments are medium- to fine-grained lake deposits (Feth and others, 1966), some deposited as an underflow fan-type delta (for example, Oviatt, 1984). Most of the landslid 's, such as the large lateral spreads south of the Ogde? River delta on the south edge of Ogden (unit clsp), clearly postdate the Provo shoreline. But between Ogden and the Weber delta (unit lpd) there is a large area of more subdued, rounded, hummocky topography (units $\mathrm{Ibs} / \mathrm{clsp}$ and $\mathrm{Ips} / \mathrm{clsp}$ ) that probably predates $\mathrm{t} \cdot \mathrm{Bon}$ neville shoreline. Near the northern end of this area of subdued terrain, north and south of Buess Rerervoir, Pashley and Wiggins (1972, p. K2-K7) have mapped two areas of coarse, bouldery landslide debris that slid off the mountain front prior to the Bonneville high stand (Van Horn and others, 1972, fig. 13). We concur that by $15 \mathrm{ka}$ the lake had transgressed orer this hummocky, preexisting topography, but except for the landslide deposits of Pashley and Wiggins (1972), we think most of this area is underlain by lateral-spread deposits rather than old landslide deposits (Nelson, 1988). Probably wave action smoothed and runded much of the irregular topography, and only a relatively thin cover of sandy and gravelly lake sediments was deposited. The horizontal shorelines preserved on the east-west-trending ridges (blocks) at the south edge of unit Ibs/clsp offer particularly strong support for this interpretation.

The extensive series of active and inactive landslides in the bluffs of the delta on either side of the Weber River are discussed by Pashley and Wiggins (1972, p. K9-K11, fig. 12-14). We did not investigate the northeast-trending fault in the delta deposits raported by Feth and others $(1966$, p. 20, 22) in sec. 21, T. 5 N., R. $1 \mathrm{~W}$. in the landslide area on the north side of the river. We speculate that it is related to landsliding or lateral spreading rather than to faulting.

\section{Hobbs and Holmes Reservoirs area}

From the Weber River south to Kaysville, the fault zone breaks into multiple traces (fig. 4). Through most of this area, the main scarp is at the base of steep bluffs below the Bonneville shoreline. Just south of the. Weber River there is a second major scarp halfway up the bluffs that we trace to south of Hobbs Reservoir, although the fault is difficult to map in this steep, forested, landslide terrain. Grabens $100-150 \mathrm{~m}$ wide and associated small faults parallel the main scarp throughout most of this area. We are confident that there is at least one major graben all along this part of the fault zone, but at some sites the graben is brried by young alluvium and colluvium (for example, at mouths of canyons between Hobbs Reservoir and Snow Creek, fig. 4). In the bluffs on the south side of the Weber River this graben has been enlarged and deepened by landsliding and fluvial erosion. Some of the more 
complex patterns of faulting, with as many as five parallel scarps, are located near small westward salients (projections) of the bedrock of the Wasatch Range where the fault abruptly changes direction. However, one very complex area at the mouth of Holmes Creek is in the center of an arcuate embayment rather than on a salient. Alluvial fans only partly bury numerous small blocks of lacustrine sand on the footwall of the fault here; probably some unrecognized landsliding is involved and a few blocks might be remnants of fans (unit afp) graded to regressional shorelines below the Provo level. Landsliding and headward erosion of drainages that trend westward through unit Ibpm in this area make it difficult to determine the westward extent of Holocene fan deposits (units af1 and afy). We did not attempt to subdivide Holocene fan deposits because the variable clay content of exposed debris-flow units in fans probably precludes meaningful comparisons of the degree of soil B-horizon development on the fans.

The Provo shoreline nearly coincides with scarps in the fault zone from Hobbs Reservoir to Kaysville, so we are uncertain of the shoreline's position in most places. In some areas, such as near Holmes Creck, the shoreline is at least partially buried by Holocene fan deposits, but it may coincide with some fault scarps near an altitude of $1,469 \mathrm{~m}(4,820 \mathrm{ft})$ here. Because we are not sure of the exact altitude of the shoreline in this area, we map some lake sands as unit lbps-these sands could have been deposited shortly before or after the fall of the lake to the Provo level. South of Kaysville we use this unit to show lake sands below the Provo shoreline that we cannot assign with confidence to either the transgressive or regressive phase of the Bonneville lake cycle.

We found only one fault scarp south of the Weber River (4.9 m of offset at the mouth of Adams Canyon) that could give a reliable late Holocene offset across the fault (fig. 4). The lack of late Holocene scarps in this area is partly due to the lack of late Holocene fans that extend across the main scarp of the fault; most fan heads are located at the scarps. Limited exposures suggest that late Holocene fans above the main scarp are commonly draped over it. Possibly, late Holocene slip events were smaller here than in the Ogden area or there may have been fewer events. However, antithetic scarps on some late Holocene fans indicate that there have been several significant recent events, and postearly-middle-Holocene slip rates are about the same in this area as they are near Ogden (fig. 2). Only two sites yield reliable middle or early Holocene (unit afy) offsets, but even at these sites too little unit afy fan sediment is preserved at the base of the scarp (too small to map on fig. 4) for us to be confident that these offsets are not maximum values. A profile across a unit afy fan directly east of Hobbs Reservoir (14 m offset across a 17-m-high scarp and graben) and a single 15-m-high scarp in the small drainage north of the Middle Fork of Kays Creck (fig. 4) give pre-late Holocene rates of $2.7 \pm 0.8 \mathrm{~mm} / \mathrm{yr}$ (fig. 2 ).

Of the 49 scarp profiles measured across scarys in Bonneville- and Provo-age deposits along this part of the fault, only a few provide reliable post-14-ka of "sets. Three profiles of about $27-\mathrm{m}$ offset on the main scarp in Bonneville-cycle deposits between the Middle Fork of Kays Creek and Holmes Reservoir (fig. 4) suggest a slip rate of $2.0 \pm 0.2 \mathrm{~mm} / \mathrm{yr}$.

\section{Kaysville-Shepards Creek area}

At the small salient east of Kaysville, the main scarp of the fault zone drops below the Provo shoreline, and maintains this relative position south to Bountiful. The fault zone is marked by a complex pattern of parallel scarps and grabens on remnants of pre-upper Holcrene fan deposits (units af2 and afp) south of Kaysville.

The 22-m-high scarp south of Baer Creek was th: site of one of the first detailed subsurface investigations of an active fault in the Great Basin. Methods used and conclusions reached at the Kaysville site by Swan and others (1980) have influenced most later studies of normal faults. Here we only briefly summarize the conclusions of Swan and others (1980) and Schwartz and Coppersmith (1984). These authors used col 'xvial wedges and correlative faulted and back-tilted graben deposits in trenches to demonstrate that at least three surface-faulting events had occurred during the riddle and late Holocene. Unfortunately, the timing of these events was poorly constrained; the two youngest events occurred within the past 1,500 years, and stratigraphic and geomorphic evidence suggest that the most recent event occurred within the past 500 years. Thus, event recurrence for the last two events seems to be $<1,000$ years. A new trench investigation of this site is in progress (J.P. McCalpin, written commun., 1988).

Crone and Harding (1984) used high-resolutic 7 reflection methods at the Kaysville site to trace the faults at shallow depths $(30-250 \mathrm{~m})$. They identified a suhsurface graben along the main fault at least twice as wide as our mapped graben and noted that there are large variations in the number of individual faults that occur adjacent to the main fault over distances of a few hundred meters.

The age information derived from the original study at the Kaysville site is insufficient to determine if slip rates have been increasing in the late Holocene. The middle Holocene fan at the site (unit af2) is displaced $11.5 \mathrm{~m}$, yielding a slip rate of $1.8(+1.0 ;-0.6) \mathrm{nmm} / \mathrm{yr}$ (Swan and others, 1980). Offsets during the two most 
recent events were 1.7 and $1.8 \mathrm{~m}$; the remaining 5-8 m of offset probably represents several earlier events. Thus, post-1.6-ka rates are $2.2 \pm 0.6 \mathrm{~mm} / \mathrm{yr}$.

Fewer scarp profiles were measured south of Kaysville, both because of the complexity of the fault zone and because of the lack of deposits of different age cut by the fault. Measuring net slip across such complex fault zones is difficult, but a field topographic profile measured across fault scarps formed on Provoshoreline-equivalent alluvial-fan deposits (unit afp) on the north side of Shepards Creek yielded an offset of about $20.5 \mathrm{~m}$. This is a minimum offset value, because the downthrown block is buried by an unknown amount of Holocene alluvium (unit af1). Perhaps a better value of net slip along this part of the Weber segment was derived from a field topographic profile measured on a single large scarp and graben about $1 \mathrm{~km}$ south of Shepards Creek. Surface offset here is about $23.5 \mathrm{~m}$ on undifferentiated gravel and sand of Lake Bonneville (unit lbps). These sites yield post-14-ka slip rates of about $1.6 \pm 0.1 \mathrm{~mm} / \mathrm{yr}$.

\section{SOUTHERN PART OF THE WEBER SEMENT}

\section{Farmington area}

The Weber segment bifurcates about $0.5 \mathrm{~km}$ northwest of the mouth of Farmington Canyon. The main fault trace trends southeastward, and a secondary trace trends south and splinters into several scarps before forming a single scarp that rejoins the main fault trace about $0.5 \mathrm{~km}$ south of the canyon mouth. In an exposure of the main fault zone on the north side of Farmington Creek, debris-flow gravels are in depositional contact with a bedrock fault plane in Precambrian metamorphic rock; the exposed fault plane dips $48^{\circ}$ to the west. These upper Holocene debris-flow deposits (too small to show at the map scale) apparently were draped over a preexisting escarpment and probably postdate the youngest movement on this strand of the fault zone.

The secondary trace is composed of at least six fault scarps north of Farmington Creek, but none of these scarps has more than about $5 \mathrm{~m}$ of surface offset. An exposure of one of the central strands in an excavation for a house revealed evidence of recurrent, probable Holocene faulting. This exposure showed a main fault dipping $76^{\circ}$ west, with $2 \mathrm{~m}$ of vertical offset, and a steeply east-dipping antithetic fault with $20 \mathrm{~cm}$ of vertical offset. The upper part of the exposure was partially disturbed by construction activity, but two wedges of fault-scarp colluvium, one in fault contact with both faults and an upper wedge in depositional contact with the main fault, were still preserved. The wedges of fault-scarp colluvium overlie Provoshoreline-equivalent pebble and cobble fluvial gravel (unit alp), which in turn overlie Provo deltaic sand and silty sand (unit lpd). These relations suggest t 1 at this fault strand has undergone two post-Provo-shreline $(<13.5 \mathrm{ka}$ ) surface-faulting events that totaled about 2 $m$ of offset. No datable materials were found in this excavation, and the exposure has since been covered by a house.

Latest Pleistocene slip rates are also high (about 1.1-1.6 mm/yr) near Farmington, although scarn topographic profiles farther south indicate that ret slip begins to decrease from the Farmington area southward (fig. 2). A topographic profile measured across the fault zone on Provo-shoreline-equivalent alluvium (unit alp) just south of Farmington Creek yielded surface offsets of about $14 \mathrm{~m}$ and $10 \mathrm{~m}$ for the upper and lower scarps, respectively. The resulting net vertical displacement $(24 \mathrm{~m})$ across the fault zone is nearly identical to that measured on the single large scarp and graben $1.5 \mathrm{~km}$ to the north.

The town of Farmington has been the site of 1 istoric, damaging debris flows that emanated from Farrington Canyon in 1923 and Rudd Canyon in 1983. Frrtially detached landslide masses present in the drainages of these two canyons indicate that the potential for future debris flows is very high (Wieczorek and other: 1983, 1989).

Another type of mass movement is well developed in the Farmington area. One of the largest examples of lateral-spread failures (unit clsp), the Farmington Siding landslide, is located west of the town of Farmington (Van Horn, 1975). This huge landslide complex formed as a result of liquefaction of unconsolidated lacustrine sediments, probably as a result of seismic shaking from one or more earthquakes in the region. Van Horn (1975) and Anderson and others (1982) divided the landslide into two separate landslides (a younger landslide to the north and an older one to the south), but our mapping has identified three landslides in this complex; they are differentiated on the map with dashed and dotted contacts. The northernmost and youngest landslide in this complex clearly postdates the Gilbert shoreline, and therefore must have formed $<10.5 \mathrm{ka}$. The Gilbert shoreline is not developed on the two older landslides in the southern part of the complex, suggesting that these landslides are also Holocene in age.

Studies of liquefaction features like those in the Farmington area may serve as additional sources of paleoseismic information. For example, Van Horn (1975) stated that the older landslide in the Farmington Siding landslide complex was $<5,000$ yr old and the younger landslide was $<2,000 \mathrm{yr}$ old, although no 
datable materials have yet been found in these deposits. If these landslides were indeed formed by largemagnitude earthquakes, then detailed study and dating of these deposits could help constrain the ages of several paleoearthquakes in the region. This data could then be compared to the growing body of paleoseismic data from trench studies of the Weber segment (Swan and others, 1980; Schwartz and Coppersmith, 1984; Nelson and others, 1987; Machette and others, 1987).

About $3 \mathrm{~km}$ south of Farmington Canyon, the main trace of the Weber segment obliquely cuts the Provo shoreline on the north edge of the mouth of Davis Creek, and is exposed in a recent road cut. At least two subsidiary fault strands were exposed in transgressive Bonneville-lake-cycle gravels, Provo shoreline sands, and pre-Bonneville-lake-cycle diamicton; the main fault plane juxtaposes these sediments against Precambrian metamorphic rock. The fault planes dip $60^{\circ}-66^{\circ}$ to the southwest. Unfortunately the upper parts of the fault zones were covered, and no datable materials were found in this exposure. A topographic profile measured on aerial photographs across the offset Provo shoreline yielded a surface offset of only $4.6 \mathrm{~m}$.

About $300 \mathrm{~m}$ south of Davis Creek, the fault trace makes an unusually sharp, right-angle bend and trends to the southwest and south. Several discontinuous scarps are located in the concavity created by this sharp bend; the small surface offset measured on the main trace at Davis Creek may be explained by the distribution of offset across the discontinuous scarps west of the main trace. The patterns of faulting near Davis Creek and that seen just north of Farmington may represent attempts by the fault to straighten its trace. Additionally, the complex fault pattern near Davis Creek also may be related to the presence of a large preBonneville-lake-cycle landslide (unit cls) that underlies this part of the mountain front. Complex fault patterns are commonly associated with these types of deposits along other parts of the Wasatch fault zone.

\section{Centerville area}

From south of the large landslide below the Bonneville shoreline near Davis Canyon to the northern outskirts of Bountiful, the Weber segment is expressed for most of its length as a large (10-23 m high), single fault scarp. This area is being rapidly developed, but examination of aerial photographs flown in 1952, prior to most of the urbanization, indicates that this is one of the least complex parts of the Weber segment. Remnants of several large fans graded to the Provo shoreline (unit afp) are preserved at the mouths of several canyons near Centerville, but the lack of scarps on Holocene fans precludes measuring offsets in younger deposits. A scarp profile about $1 \mathrm{~km}$ north of Picks Creek (20 m offset) yields a post-Provo-shoreline slip rate of $1.5 \pm 0.2 \mathrm{~mm} / \mathrm{yr}$; however, offsets of $15 \mathrm{~m}$ and 16 $\mathrm{m}$ on either side of Parrish Creek, and $14 \mathrm{~m}$ south of Centerville Canyon, show slip rates have decreased near Centerville to about $1.1 \pm 0.2 \mathrm{~mm} / \mathrm{yr}$.

Just north and west of Rosedale, two fault-scarp-like features are present on the valley floor. The short, low scarp north of Rosedale is almost certainly a fault because it probably displaces Holocene fan alluvium (unit afy), and clearly does not parallel the topographic slope as shorelines in the map area do. The origin of the $1.7-\mathrm{km}$-long scarp west of Rosedale is more prol!ematic. At its northern end, this feature is developed on lacustrine mud (unit lbpm) and trends parallel to the topographic slope near the altitude of the Gilbert shoreline. However, the middle and southern parts of the scarp cut downslope, and young lake sediment is ponded against the low, west-facing scarp. The lin arity of the scarp suggests that this feature is not related to landsliding and, therefore, is probably a fault scarp, although other origins cannot be ruled out.

Crawford and Thackwell (1931) reported an important exposure of the main trace of the fault created in lacustrine sediments at the mouth of Ricks Creek ("Ford Creek" in their paper) during a flood in 1930. Stratified Bonneville-lake-cycle sand and gravel were seen to be displaced at least $10 \mathrm{~m}$ by a fault dippin $60^{\circ}$, but this is a minimum offset of the Bonneville de yosits because no correlative deposits were visible ant because the footwall had been eroded an unknown amount. Crawford and Thackwell (1931, plate VI) also showed backtilting and antithetic faulting of fontwall sediments. Lower in the exposure, where the stratified sand of the hanging wall was seen to be in fault contact with Precambrian gneiss in the footwall, the fault apparently dipped about $30^{\circ}$. These exposures have now been covered by colluvium.

\section{Bountiful area}

On the northeast edge of Bountiful, the fault turns southeastward, and a single, easily identified scarp is visible only as far south as Stone Creek. Along the section of the fault zone from Centerville to Stone Creek, net offset gradually decreases from 11 to $8.5 \mathrm{~m}$. Larger offsets farther south show that the $5.8-\mathrm{m}$ offset measured on the north edge of Stone Creek is a minimum value.

South of Stone Creek, several parallel scarps trend south to Mill Creek, but we are less confident of a tectonic origin for all the scarps in this area. Residential development here affects the entire area, so our mapping is based almost entirely on 1952 aerial photo- 
graphs. Most scarps south of Stone Creek cut the remnants of a Provo delta and shoreline deposits, and the scarps are sometimes coincident with the Provo shoreline in places. In addition, these Provo deposits are very sandy and erode easily, so a few of the parallel scarps might be wave-cut shorelines rather than fault scarps. Other regressional shorelines and a few features that may be the headscarps of small lateral spreads occur below the Provo shoreline. Our mapping of the fault zone in this area is conservative; we show only scarps that we are reasonably sure were formed by surface faulting.

Offset measurements across the main scarps indicate a post-Provo slip rate of about $0.7 \pm 0.2 \mathrm{~mm} / \mathrm{yr}$ in the Bountiful area. A single 4.3-m offset scarp on a middle or early Holocene fan (unit afy) halfway between Stone Creek and Holbrook Creek suggests a similar Holocene slip rate. Thus, offsets and corresponding post-14-ka and Holocene slip rates decrease significantly near Bountiful, near the southern end of the Weber segment (fig. 2).

\section{South boundary of the Weber segment}

The boundary between the southern end of the Weber segment and the northern end of the Salt Lake City segment is located on the northern flank of the Salt Lake salient, a large block of mostly Tertiary bedrock on the hanging wall of the Wasatch fault zone. Gilbert $(1890,1928)$ first recognized that the salient was one of several large bedrock spurs that controlled the geometry of the Wasatch fault zone. Most of these spurs are probable segment boundaries (Schwartz and Coppersmith, 1984; Machette and others, 1987, in press; Wheeler and Krystinik, 1988).

Again, because of extensive urban development near Bountiful, our mapping along the north side of the salient is based largely on 1952 aerial photography. A series of small, parallel scarps displaces a large area of shallow landslides in a thick sequence of Bonneville lacustrine sand with some gravel (unit lbg) just south of Mill Creek. The main scarp (3-7 m high) continues to the southwest across the drainage of North Canyon, and then trends south, offsetting the Bonneville shoreline before dying out in the mountain block. Topographic profiles measured across this single scarp near North Canyon yielded surface offsets of $6-12 \mathrm{~m}$ on Bonneville lacustrine gravel and sand (unit $\mathrm{lbg}$ ) and about $4 \mathrm{~m}$ in Holocene fan alluvium (unit af2). These scarp measurements indicate that slip on the Weber segment at the south boundary of the segment has been occurring at about $0.6 \pm 0.2 \mathrm{~mm} / \mathrm{yr}$ for the last $1,500 \mathrm{yr}$.

Several short, gently west-sloping, north-trending scarps are preserved in the $2-\mathrm{km}$-wide gap between the southern end of the Weber segment and the northern end of the Warm Springs fault on the Salt Lake City segment. These short, low (2-5 m high) scarps may be part of a network of subsidiary faults like those seen on the Pleasant View salient at the northern end of the Weber segment (Personius, 1988a, in press). Ho"vever, far fewer of these low, short scarps have been mapped on the Salt Lake salient because gravel mining, urban development, the presence of numerous shorelines, and dissection of the sandy lacustrine deposits maker identification of scarps difficult. For example, in 1901, G.K. Gilbert photographed a 5- to 7-m-high scarp (USGS Photographic Library, Gilbert Archive No. 1787) on the Warm Springs fault where it bends northeastward, about $1 \mathrm{~km}$ north of the southern map boundary; this scarp has long since been destroyed by gravel mining. Several anomalous drainage alignments in thi: area suggest that other small subsidiary faults are present on the north flank of the Salt Lake salient.

\section{REFERENCES CITED}

Anderson, L.R., Keaton, J.R., Aubry, Kevin, and Ell: ${ }^{\circledR}$ S.J., 1982, Liquefaction potential map for Davis County, Utah: Report to U.S. Geological Survey for Contract No. 14-08-0001-19127, Department of Civil and Environmental Engineering, Utah State University, Logan, Utah, and Dames and Moore Consulting: Engineers, Salt Lake City, Utah, February 1982,59 p., 8 plates.

Birkeland, P.W., 1984, Soils and geomorphology: New York, Oxford University Press, 372 p.

Bonilla, M.G., Mark, R.K., and Lienkaemper, J.J., 1984, Statistical relations among earthquake magnitude, surface rupture length, and surface fault displac?ment: Bulletin of the Seismological Society of America, v. 74, p. 2379-2411.

Bruhn, R.L., Gibler, P.R., and Parry, W.T., 1987, R vpture characteristics of normal faults-An example from the Wasatch fault zone, Utah, in Coward, M.P., Jewey, J.F., and Hancock, P.L., eds., Continental extensional tectonics: Geological Society of London Special Publication No. 28, p. 337-353.

Bryant, Bruce, 1984, Reconnaissance geologic map of the Precambrian Farmington Canyon complex ard surrounding rocks in the Wasatch Mountains between Ogden and Bountiful, Utah: U.S. Geological Survey Miscellaneous Investigations Series Map I-1447, scale 1:50,000.

Bucknam, R.C., and Anderson, R.E., 1979, Estimation of fault-scarp ages from a scarp-height-slope-angle relationship: Geology, v. 7, p. 11-14.

Cluff, L.S., Brogan, G.E., and Glass, C.E., 1970, W'asatch fault, northern portion, earthquake fault invest 'sation and evaluation-A guide to land-use planning: Oakland, Calif., Woodward-Clyde and Associates, 27 p., 21 plates at $1: 24,000$ scale, 7 plates at 1:12,000 scale. 
Crawford, A.L., and Thackwell, F.E., 1931, Some aspects of the mudflows north of Salt Lake City, Utah: Proceedings of Utah Academy of Sciences, v. 8, p. 97-105.

Crittenden, M.D., Jr., and Sorensen, M.L., 1985, Geologic map of the North Ogden quadrangle and part of the Ogden and Plain City quadrangles, Box Elder and Weber Counties, Utah: U.S. Geological Survey Misce1laneous Investigations Series Map I-1606, scale $1: 24,000$.

Crone, A.J., and Harding, S.T., 1984, Near-surface faulting associated with Holocene fault scarps, Wasatch fault zone, Utah-A preliminary report, in Hays, W.W., and Gori, P.L., eds., Proceedings of Conference XXVI-A workshop on evaluation of regional and urban earthquake hazards and risk in Utah: U.S. Geological Survey Open-File Report 84-763, p. 241-268.

Crone, A.J., Machette, M.N., Bonilla, M.G., Lienkaemper, J.J., Pierce, K.L., Scott, W.E., and Bucknam, R.C., 1987, Surface faulting accompanying the Borah Peak earthquake and segmentation of the Lost River fault, central Idaho: Bulletin of the Seismological Society of America, v. 77, no. 3, p. 739-770.

Currey, D.R., 1980, Coastal geomorphology of Great Salt Lake and vicinity, in Gwynn, J.W., ed., Great Salt Lake-A scientific, historical, and economic overview: Utah Geological and Mineral Survey Bulletin 116, p. $69-82$, plate 1 at $1: 250,000$ scale.

Currey, D.R., Atwood, Genevieve, and Mabey, D.R., 1984, Major levels of Great Salt Lake and Lake Bonneville: Utah Geological and Mineral Survey Map 73, scale 1:750,000.

Currey, D.R., and Burr, T.N., 1988, Linear model of threshold-controlled shorelines of Lake Bonneville, in Machette, M.N., ed., In the footsteps of G.K. GilbertLake Bonneville and neotectonics of the eastern Basin and Range province, Geological Society of America Guidebook to Field Trip 12: Utah Geological and Mineral Survey Miscellaneous Publication 88-1, p. 104-110.

Currey, D.R., and Oviatt, C.G., 1985, Durations, average rates, and probable causes of Lake Bonneville expansion, still-stands, and contractions during the last deeplake cycle, 32,000 to 10,000 yrs ago, in Kay, P.A., and Diaz, H.F., eds., Problems of and prospects for predicting Great Salt Lake levels-Proceedings of a NOAA Conference, March 26-28, 1985: Salt Lake City, Utah, University of Utah, Center for Public Affairs and Administration, p. 9-24.

Davis, F.D., 1983, Geologic map of the central Wasatch Front, Utah: Utah Geological and Mineral Survey Map 54-A, scale 1:100,000.

1985, Geology of the northern Wasatch front: Utah Geological and Mineral Survey Map 53-A, 2 sheets, scale $1: 100,000$.

dePolo, C.M., Clark, D.G., Slemmons, D.B., and Aymard, W.H., 1989, Historical Basin and Range province surface faulting and fault segmentation, in Schwartz, D.P., and Sibson, R.H., eds., Proceedings of Conference
XLV-Fault segmentation and controls on rupture initiation and termination: U.S. Geological Survey Open-File Report 89-315, p. 131-162.

Doser, D.I., 1989, The character of faulting processes of earthquakes in the Intermountain region, in Schwartz, D.P., and Sibson, R.H., eds., Proceedings of Conference XLV-Fault segmentation and controls on rupture initiation and termination: U.S. Geological Survey Open-File Report 89-315, p. 163-180.

Eardley, A.J., 1944, Geology of the north-central Waratch Mountains, Utah: Geological Society of America Bulletin, v. 55, p. 819-894.

Erickson, A.J., and Wilson, Lemoyne, 1968, Soil survey, Davis-Weber area, Utah: U.S. Soil Conservation Service, $149 \mathrm{p}$.

Feth, J.H., 1955, Sedimentary features in the Lake Bonneville Group in the east shore area, near Ogden, Utzh, in Tertiary and Quaternary geology of the eastern Bonneville Basin: Salt Lake City, Utah, Utah Geolcogical Society, Guidebook to the Geology of Utah, No. 10, p. 45-69.

Feth, J.H., Barker, D.A., Moore, L.G., Brown, R.J., and Veirs, C.E., 1966, Lake Bonneville-Geology and hydrology of the Weber delta district, including Ogden, Utah: U.S. Geological Survey Professional Paper 518, 76 p., 9 plates.

Fonseca, Julia, 1988, The Sou Hills-A barrier to faulting in the central Nevada seismic belt: Journal of Geoph"rsical Research, v. 93, p. 475-489.

Forman, S.L., Maat, Paula, and Jackson, M.E., 1988, Thermoluminescence dating of paleoearthquakes-Recent results and future prospects: Geological Society of America Abstracts with Programs, v. 20, no. 3, p. 161.

Gilbert, G.K., 1890, Lake Bonneville: U.S. Geological S^rvey Monograph 1, 438 p.

1928, Studies of Basin-Range structure: U.S. Geological Survey Professional Paper 153, 92 p.

Hanks, T.C., Bucknam, R.C., Lajoie, K.R., and Wallace, R.E., 1984, Modification of wave-cut and faulting-controlled landforms: Journal of Geophysical Research, v. 89, p. $5771-5790$.

Jarrett, R.D., and Malde, H.E., 1987, Paleodischarge of late Pleistocene Bonneville Flood, Snake River, Idaho, computed from new evidence: Geological Society of America Bulletin, v. 99, p. 127-134.

Keaton, J.R., 1986, Landslide inventory and preliminary hazard assessment, southeast Davis County, Utah: Association of Engineering Geologists, 29th Annual Meeting, San Francisco, Calif., Abstracts with Programs, p. 53.

1988, A probablistic model for hazards relatid to sedimentary processes on alluvial fans, Davis County, Utah: College Station, Texas, Texas A \& M University, Dept. of Geology Ph. D. thesis, 441 p.

King, Geoffrey, and Nabelek, John, 1985, Role of fault bends in the initiation and termination of fault rupture: Science, v. 228, p. 984-987. 
Machette, M.N., 1982, Quaternary and Pliocene faults in the La Jencia and southern part of the Albuquerque-Belen basins, New Mexico-Evidence of fault history from fault scarp morphology and Quaternary history, in Grambling, J.A., and Wells, S.G., eds., Albuquerque Country II: New Mexico Geological Society Guidebook, 33rd Field Conference, p. 161-169.

1984, Preliminary investigations of late Quaternary slip rates along the southern part of the Wasatch fault zone, central Utah, in Hays, W.W., and Gori, P.L., eds., Proceedings of Conference XXVI-A workshop on evaluation of regional and urban earthquake hazards and risk in Utah: U.S. Geological Survey Open-File Report 84-763, p. 391-406.

1985, Calcic soils of the southwestern United States, in Weide, D.L., ed., Soils and Quaternary geology of the southwestern United States: Geological Society of America Special Paper 203, p. 1-23.

1988, Quaternary movement along the La Jencia fault, central New Mexico: U.S. Geological Survey Professional Paper 1440, 82 p.

1989, Preliminary surficial geologic map along the Wasatch fault zone in the eastern part of the Utah Valley, Utah County, and parts of Salt Lake and Juab Counties, Utah: U.S. Geological Survey Miscellaneous Field Studies Map MF-2109, scale 1:50,000.

in press, Surficial geologic map along the Wasatch fault zone in the eastern part of the Utah Valley, Utah County, and parts of Salt Lake and Juab Counties, Utah: U.S. Geological Survey Miscellaneous Investigations Series Map I-2095, scale 1:50,000.

Machette, M.N., Personius, S.F., and Nelson, A.R., 1987, Quaternary geology along the Wasatch fault zoneSegmentation, recent investigations, and preliminary conclusions, in Gori, P.L., and Hays, W.W., eds., Assessment of regional earthquake hazards and risk along the Wasatch Front, Utah: U.S. Geological Survey Open-File Report 87-585, v. 1, Chapter A, p. A1-A72. in press, Paleoseismology of the Wasatch fault zone-A summary of recent investigations, conclusions, and interpretations, in Gori, P.L., and Hays, W.W., eds., Assessing regional earthquake hazards and risk along the Wasatch Front, Utah: U.S. Geological Survey Professional Paper 1500-A.

Machette, M.N., Personius, S.F., Nelson, A.R., Schwartz, D.P., and Lund, W.R., 1989, Segmentation models and Holocene movement history of the Wasatch fault zone, Utah, in Schwartz, D.P., and Sibson, R.H., eds., Proceedings of Conference XLV-Fault segmentation and controls on rupture initiation and termination: U.S. Geological Survey Open-File Report 89-315, p. 229-245.

Malde, H.E., 1968, The catastrophic late Pleistocene Bonneville Flood in the Snake River Plain: U.S. Geological Survey Professional Paper 596, 52 p.

Marsell, R.E., ed., 1964, The Wasatch fault zone in north central Utah: Salt Lake City, Utah, Utah Geological Society, Guidebook to the geology of Utah, No. 18, $62 \mathrm{p}$.
Mayer, Larry, 1984, Dating Quaternary fault scarps formed in alluvium using morphologic parameters: Quaternary Research, v. 22, p. 300-313.

McCalpin, James, 1989, Surficial geologic map of the East Cache fault zone, Cache County, Utah: U.S. Geological Survey Miscellaneous Field Studies Map MF-2107, scale 1:50,000.

McCoy, W.D., 1987, Quaternary aminostratigraphy of the Bonneville Basin, western United States: Geological Society of America Bulletin, v. 98, p. 99-112.

Miller, R.D., 1980, Surficial geologic map along part of the Wasatch Front, Salt Lake Valley, Utah: U.S. Geological Survey Miscellaneous Field Studies Map MF-1198, 2 sheets, scale 1:100,000.

Morisawa, Marie, 1972, The Wasatch fault zone-General aspects, in Environmental geology of the Wrsatch Front, 1971: Salt Lake City, Utah, Utah Geological Association Publication 1, p. D1-D17.

Mulvey, W.E., 1985, Reconstruction and interpretation of Late Pleistocene equilibrium-line altitudes in the Lake Bonneville region [Utah]: Salt Lake City, Utah, University of Utah, Dept. of Geography M.S. thesis, 65 p., maps at $1: 24,000$ scale.

Nash, D.B., 1984, Morphologic dating of fluvial terrace scarps and fault scarps near West Yellowstone, Mortana: Geological Society of America Bulletin, v. 95, p. 249-266.

Nelson, A.R., 1988, The northern part of the Weber segment of the Wasatch fault zone near Ogden, Utah, ir Machette, M.N., ed., In the footsteps of G.K. GilbertLake Bonneville and neotectonics of the erstern Basin and Range province, Geological Society of $f$ merica Guidebook to Field Trip 12: Utah Geologica1 and Mineral Survey Miscellaneous Publication 88-1, p. 33-37.

Nelson, A.R., Klauk, R.H., Lowe, Michael, and Garr, J.D., 1987, Holocene history of displacement on the V'eber segment of the Wasatch fault zone at Ogden, northern Utah: Geological Society of America Abstracts with Programs, v. 19, no. 5, p. 322.

Nelson, A.R., and Personius, S.F., 1987, A nonconser'ative barrier to Holocene rupture propagation in the rorthern Wasatch fault zone, Utah, USA: International Union for Quaternary Research, 12th International Congress, Ottawa, Canada, July 31-August 9, 1987, Programme with Abstracts, p. 231.

North American Commission on Stratigraphic Nomenclature, 1983, North American stratigraphic code: American Association of Petroleum Geologists Bulletin, ". 67, p. 841-875.

Oviatt, C.G., 1984, Lake Bonneville stratigraphy at the Old River Bed and Leamington, Utah: Salt Lake City, Utah, University of Utah, Dept. of Geography Ph. D. thesis, $122 \mathrm{p}$.

Pashley, E.F., Jr., and Wiggins, R.A., 1972, Landslides of the northern Wasatch Front, in Environmental geolcgy of the Wasatch Front, 1971: Salt Lake City, Utah, Utah Geological Association Publication 1, p. K1-K16. 
Personius, S.F., 1986, The Brigham City segment-A new segment of the Wasatch fault zone, northern Utah: Geological Society of America Abstracts with Programs, v. 18, no. 5, p. 402.

1988a, Preliminary surficial geologic map of the Brigham City segment and adjacent parts of the Weber and Collinston segments, Wasatch fault zone, Box Elder and Weber Counties, Utah: U.S. Geological Survey Miscellaneous Field Studies Map MF-2042, scale $1: 50,000$.

$1988 \mathrm{~b}$, A brief summary of the surficial geology along the Brigham City segment of the Wasatch fault zone, Utah, in Machette, M.N., ed., In the footsteps of G.K. Gilbert-Lake Bonneville and neotectonics of the eastern Basin and Range province, Geological Society of America Guidebook to Field Trip 12: Utah Geological and Mineral Survey Miscellaneous Publication 88-1, p. 27-32.

in press, Surficial geologic map of the Brigham City segment and adjacent parts of the Weber and Collinston segments, Wasatch fault zone, Box Elder and Weber Counties, Utah: U.S. Geological Survey Miscellaneous Investigations Series Map I-1979, scale $1: 50,000$.

Personius, S.F., and Scott, W.E., 1990, Preliminary surficial geologic map of the Salt Lake City segment and parts of adjacent segments of the Wasatch fault zone, Davis, Salt Lake, and Utah Counties, Utah: U.S. Geological Survey Miscellaneous Field Studies Map MF-2114, scale $1: 50,000$.

in press, Surficial geologic map of the Salt Lake City segment and parts of adjacent segments of the Wasatch fault zone, Davis, Salt Lake, and Utah Counties, Utah: U.S. Geological Survey Miscellaneous Investigations Series Map I-2106, scale 1:50,000.

Petersen, J.F., 1981, Topographic profile analysis of piedmont scarps, northern Wasatch Front, Utah: Salt Lake City, Utah, University of Utah, Dept. of Geography Ph. D. thesis, $125 \mathrm{p}$.

Pierce, K.L., and Colman, S.M., 1986, Effect of height and orientation (microclimate) on geomorphic degradation rates and processes, late-glacial terrace scarps in central Idaho: Geological Society of America Bulletin, v. 97, p. 869-885.

Pitty, A.F., 1968, A simple device for the field measurement of hillslopes: Journal of Geology, v. 76, p. 717-720.

Schwartz, D.P., and Coppersmith, K.J., 1984, Fault behavior and characteristic earthquakes-Examples from the Wasatch and San Andreas fault zones: Journal of Geophysical Research, v. 89, p. 5681-5698.

1986, Seismic hazards-New trends in analysis using geologic data, chapter 14 , in Wallace, R.E., panel chairman, Active tectonics-Studies in geophysics: Washington, D.C., National Academy Press, p. 215-230.

Scott, W.E., 1988a, Transgressive and high-shore deposits of the Bonneville lake cycle near North Salt Lake, Utah, in Machette, M.N., ed., In the footsteps of G.K. GilbertLake Bonneville and neotectonics of the eastern
Basin and Range province, Geological Society of America Guidebook to Field Trip 12: Utah Geological and Mineral Survey Miscellaneous Publication 88-1, p. 38-42.

1988b, Temporal relations of lacustrine and g'acial events at Little Cottonwood and Bells Canyons, Utah, in Machette, M.N., ed., In the footsteps of G.K. Gilbert-Lake Bonneville and neotectonics of the eastern Basin and Range province, Geological Society of America Guidebook to Field Trip 12: Utah Geolc gical and Mineral Survey Miscellaneous Publication 88-1, p. 78-81.

Scott, W.E., McCoy, W.D., Shroba, R.R., and Rubin, Mayer, 1983, Reinterpretation of the exposed record of the last two cycles of Lake Bonneville, western United States: Quaternary Research, v. 20, p. 261-285.

Scott, W.E., and Shroba, R.R., 1985, Surficial geologic map of an area along the Wasatch fault zone in the Salt Lake valley, Utah: U.S. Geological Survey Open-File Report 85-448, 2 plates, scale 1:24,000.

Scott, W.E., Shroba, R.R., and McCoy, W.D., 1982, Gridebook for the 1982 Friends of the Pleistocene, F ocky Mountain Cell, Field trip to central Utah, Part I-Little Valley and Jordan Valley, Utah: U.S. Geological Survey Open-File Report 82-845, 59 p.

Shroba, R.R., 1982, Soil B-horizon properties as age irdicators for late Quaternary deposits along the Wasatch front, north-central Utah: Geological Society of A merica Abstracts with Programs, v. 14, no. 4, p. 233.

1984 , Soil properties and loess mantles as age indicators for Holocene deposits in alpine and semiarid regicns of Colorado and Utah: Geological Society of Arrerica Abstracts with Programs, v. 16, no. 4, p. 255.

Swan, F.H., III, Schwartz, D.P., and Cluff, L.S., 1980, Recurrence of moderate to large magnitude earthqrakes produced by surface faulting on the Wasatch fault zone, Utah: Bulletin of the Seismological Society of Amarica, v. 70, p. 1431-1462.

Thatcher, Wayne, and Bonilla, M.G., 1989, Earthquake fault slip estimation from geologic, geodetic and seismologic observations-Implications for earthquake mecl anics and fault segmentation, in Schwartz, D.P., and Sibson, R.H., eds., Proceedings of Conference XLV-Fault segmentation and controls on rupture initiatior and termination: U.S. Geological Survey Open-File Report 89-315, p. 386-399.

Thenhaus, P.C., and Barnhard, T.P., 1989, Regional ternination and segmentation of Quaternary fault belts in the Great Basin, Nevada and Utah: Bulletin of the Se'smological Society of America, v. 79, p. 1426-1438.

Van Horn, Richard, 1975, Largest known landslide of it: type in the United States-A failure by lateral spreading in Davis County, Utah: Utah Geology, v. 2, n?. 1, p. 83-88.

1981, Geologic map of pre-Quaternary rocks of the Salt Lake City North quadrangle, Davis and Salt Lake Counties, Utah: U.S. Geological Survey Miscellaneous Investigations Series Map I-1330, scale 1:24,000. 
1982, Surficial geologic map of the Salt Lake City North quadrangle, Davis and Salt Lake Counties, Utah: U.S. Geological Survey Miscellaneous Investigations Series Map I-1404, scale 1:24,000.

Van Horn, Richard, Baer, J.L., and Pashley, E.F., Jr., 1972, Landslides along the Wasatch Front, Utah, in Environmental geology of the Wasatch Front, 1971: Salt Lake City, Utah, Utah Geological Association Publication 1, p. J1-J16.

Van Horn, Richard, and Crittenden, M.D., Jr., 1987, Map showing surficial units and bedrock geology of the Fort Douglas quadrangle and parts of the Mountain Dell and Salt Lake City North quadrangles, Davis, Salt Lake, and Morgan Counties, Utah: U.S. Geological Survey Miscellaneous Investigations Series Map I-1762, scale $1: 24,000$.

Wallace, R.E., 1970, Earthquake recurrence intervals on the San Andreas fault: Geological Society of America Bulletin, v. 81, p. 2875-2890.

Wheelcr, R.L., 1989, Persistent segment boundaries on BasinRange normal faults, in Schwartz, D.P., and Sibson, R.H., eds., Proceedings of Conference XLV-Fault segmentation and controls on rupture initiation and termination: U.S. Geological Survey Open-File Report 89-315, p. 432-444.

Wheeler, R.L., and Krystinik, K.B., 1988, Segmentation of the Wasatch fault zone, Utah-Summaries, analyses, and interpretations of geological and geophysical data: U.S. Geological Survey Bulletin 1827, 47 p.

Wieczorek, G.F., Ellen, S.D., Lips, E.W., Cannon, S.H., and Short, D.N., 1983, Potential for debris flow and debris flood along the Wasatch Front between Salt Lake City and Willard, Utah, and measures for their mitigation: U.S. Geological Survey Open-File Report 83-635, 45 p.

Wieczorek, G.F., Lips, E.W., and Ellen, S.D., 1989, Debris flows and hyperconcentrated floods along the Wasatch Front, Utah, 1983 and 1984: Bulletin of the Association of Engineering Geologists, v. 26, p. 191-208.

Willman, H.B., and Frye, J.C., 1970, Pleistocene stratigraphy of Illinois: Illinois State Geological Survey Bulletin 94, 204 p.

Wood, S.H., 1984, Contemporary vertical tectonics along the Wasatch fault zone measured by repeated geodetic leveling, in Hays, W.W., and Gori, P.L., eds., Proceedings of Conference XXVI-A workshop on evaluation of regional and urban earthquake hazards and risk in Utah: U.S. Geological Survey Open-File Report $84-763$, p. 269-285.

Zoback, M.L., 1983, Structure and Cenozoic tectonics along the Wasatch fault zone, Utah, in Miller, D.M., Todd, V.R., and Howard, K.A., eds., Tectonics and stratigraphy of the eastern Great Basin: Geological Society of America Special Paper 157, p. 3-27. 


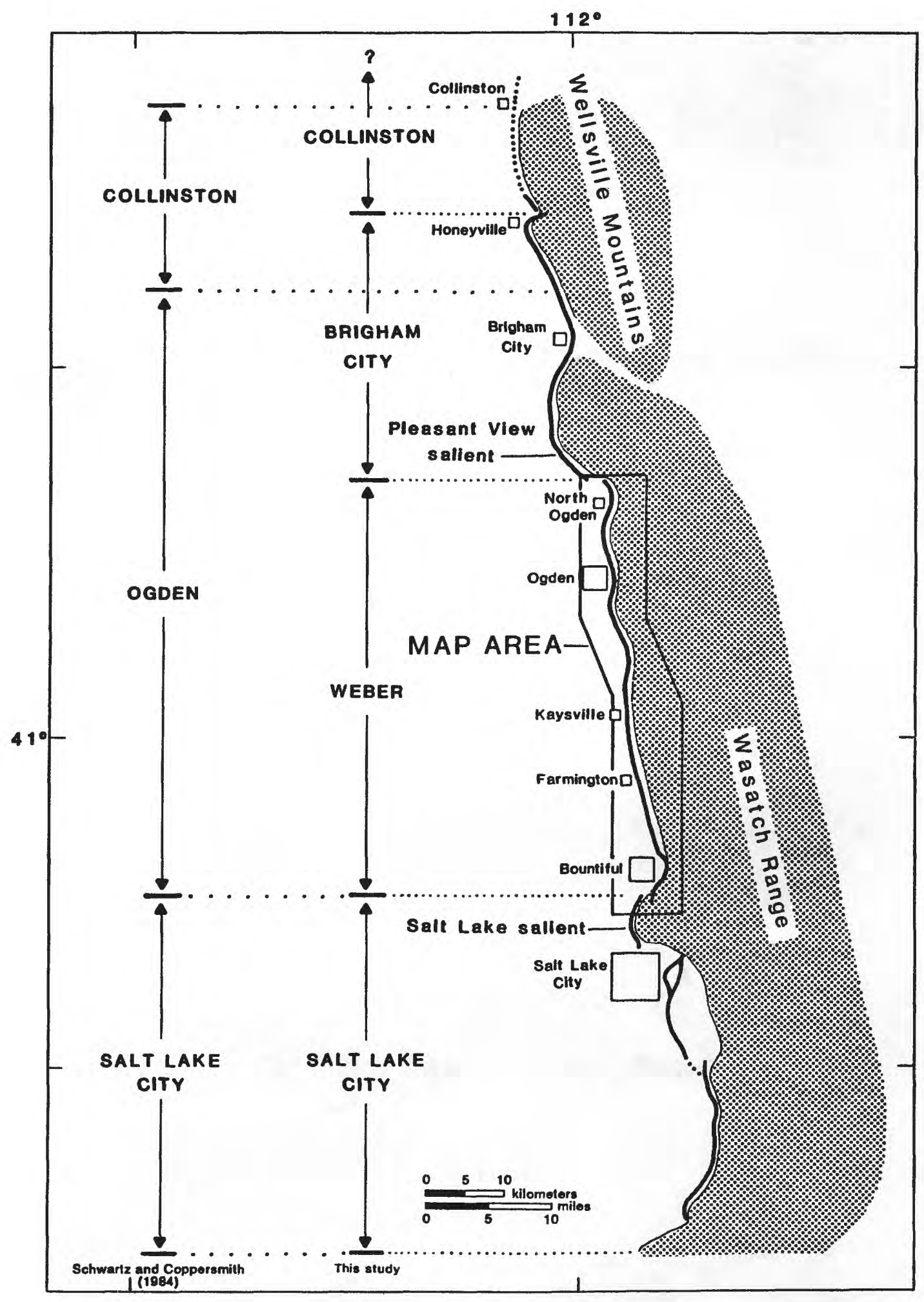

Figure 1.-Index map showing simplified trace (heavy line; dotted where concealed) of Wasatch fault zone, northern Utah. The extent of the Collinston, Brigham City, Weber, and Salt Lake City segments of this study (Machette and others, 1987, in press) is compared with that of previously used (Schwartz and Coppersmith, 1984) fault segment nomenclature. 
Figure 2 (next page).-Surface offsets calculated from topographic profiles across fault scarps on uppermost Pleistocene and Holocene deposits along the Weber segment. Offsets in meters are shown for $A$, younger late Holocene scarps (open circles, $<2 \mathrm{ka}$ estimated age) and older late Holocene scarps (solid squares, 2-4 ka estimated age), and $B$, early and middle Holocene scarps (crosses, 4-7 ka estimated age) and latest Pleistocene scarps (solid triangles, 13-16 ka). Note scale differences between $A$ and $B$ and that $A$ covers only the northern 40 $\mathrm{km}$ of the Weber segment. Offsets shown by symbols on this figure ( 63 of a total of 375 scarp measurements) represent our most reliable offsets at selected sites; these values probably have errors of less than \pm 10 percent. Other offsets are either maximum or minimum values (see text), but they help constrain slip rates along the fault. Shaded areas show estimated envelopes of offset across scarps on each age group of deposits based on these maximum and minimum offsets. Queries mark parts of the segment where we lack offset information. Italicized numbers are approximate average slip rates $(\mathrm{mm} / \mathrm{yr})$ for the indicated part of the fault based on the offset envelopes and our deposit ages. Slip rates calculated from detailed data at some selected sites (discussed in the text) may differ somewhat from these values. Note that although the thickness of the envelope for early and middle Holocene scarps is thinner than the thickness of the latest Pleistocene envelope, the uncertainty in pre-late Holocene slip rates is greater than the uncertainty in latest Pleistocene slip rates because the age of pre-upper Holocene deposits is more uncertain. Distance along the Weber segment is measured along 3- to 8-km-long straight-line segments parallel to the fault zone, beginning at the head of Barrett Canyon at the north end of the segment and continuing to the south end of the segment on the north flank of the Salt Lake salient. 
LATE HOLOCENE SCARPS

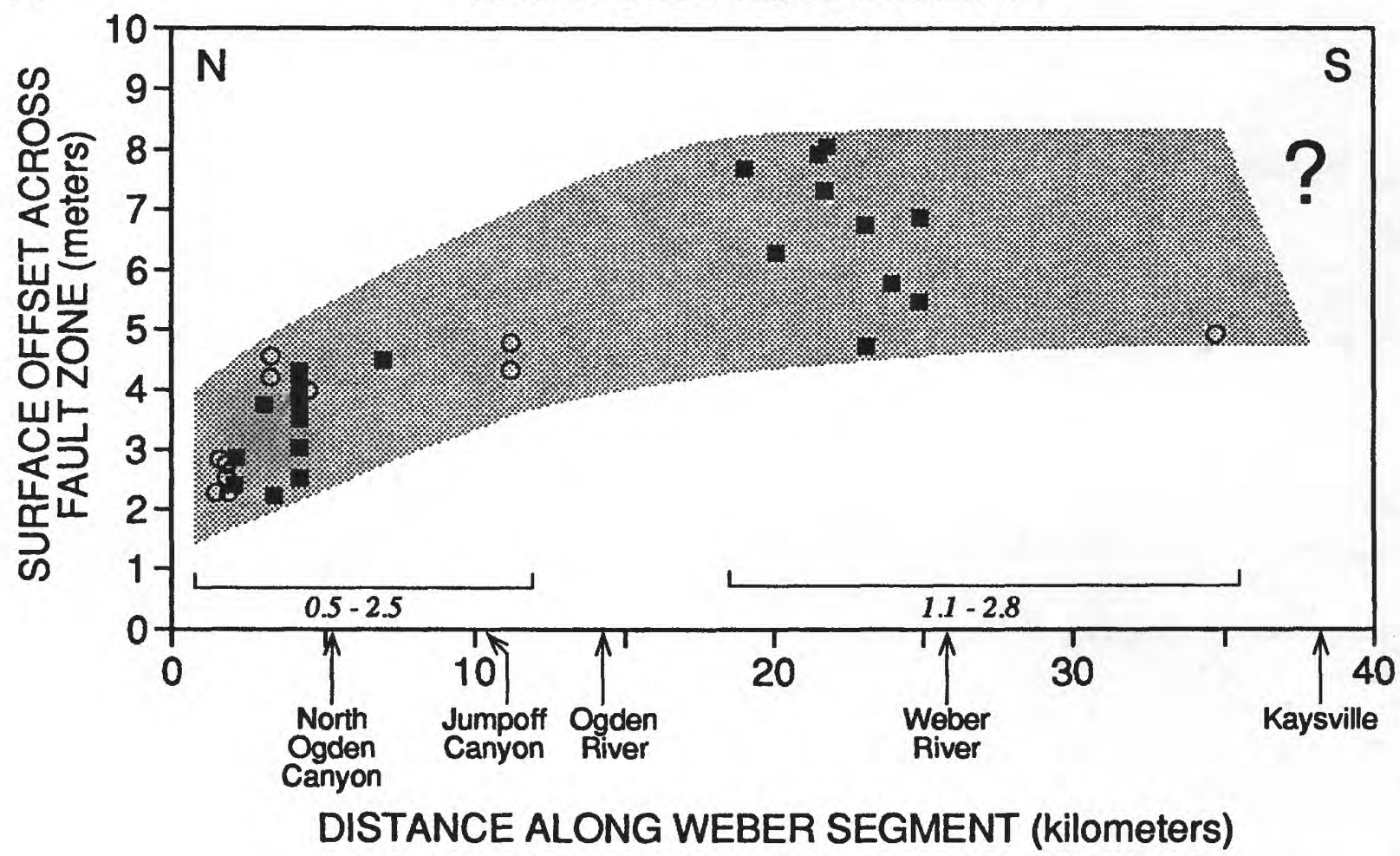

B

LATEST PLEISTOCENE (<15 ka) TO MIDDLE HOLOCENE SCARPS

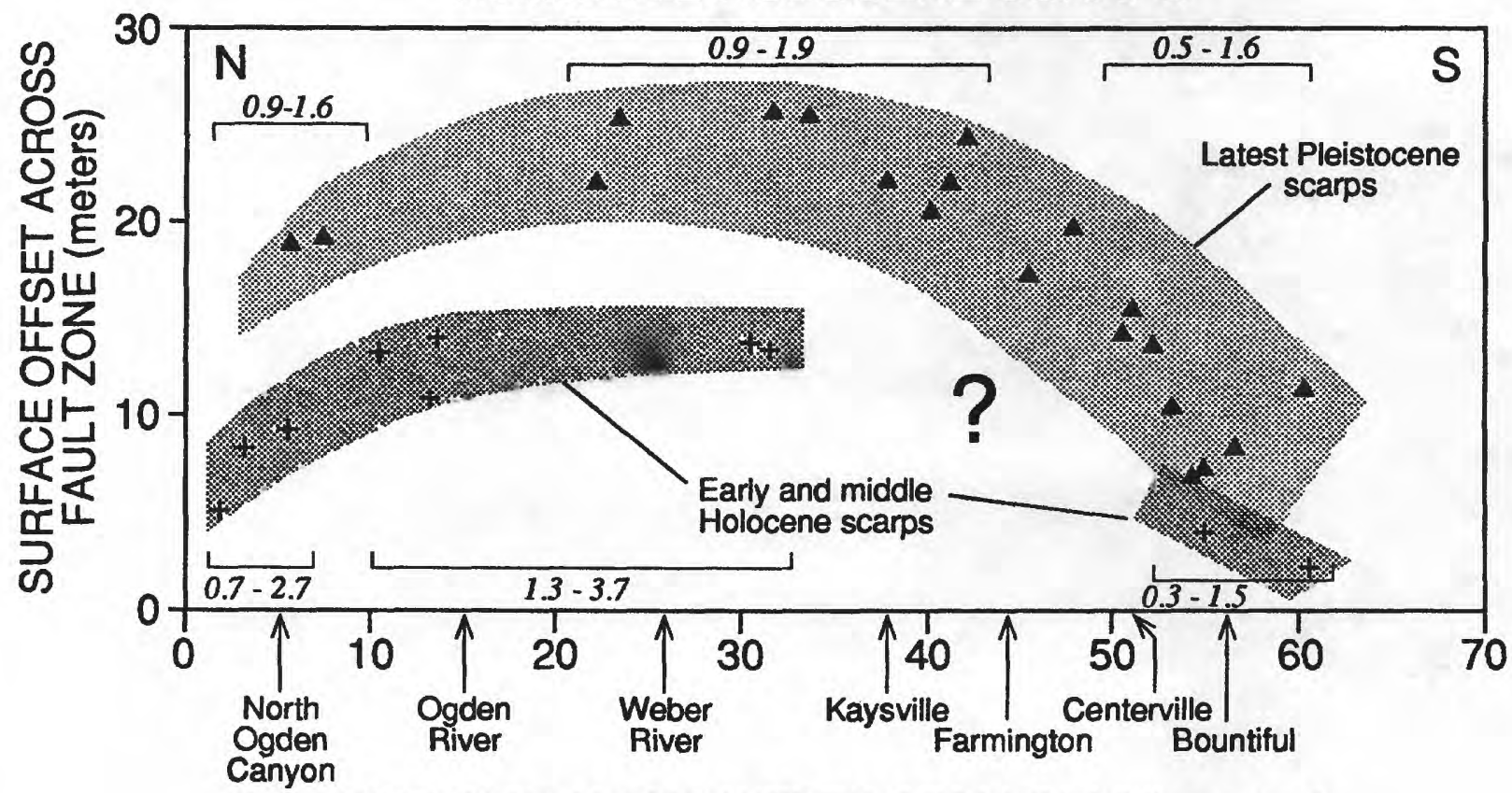

DISTANCE ALONG WEBER SEGMENT (kilometers) 